\title{
INTERNATIONAL SCIENTIFIC AND CURRENT RESEARCH CONFERENCES
}

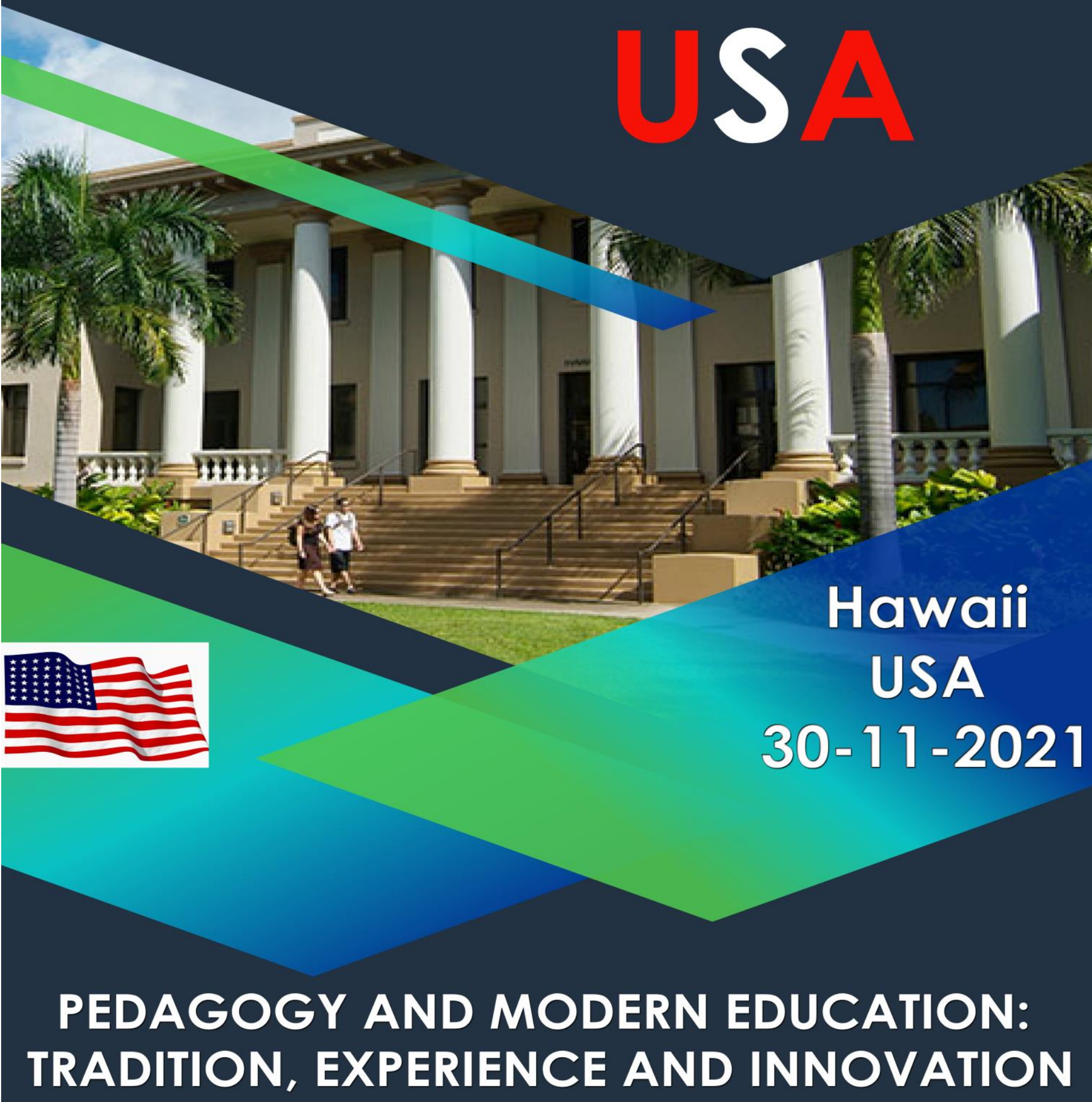

\section{$10.37547 /$ iscrs-intconf 15}




\title{
INTERNATIONAL SCIENTIFIC AND CURRENT
}

\author{
RESEARCH CONFERENCES
}

\section{"PEDAGOGY AND MODERN EDUCATION: TRADITION, EXPERIENCE AND INNOVATION"}

\section{CONFERENCE DATE}

$$
\text { 30-11-2021 }
$$

Doi - https://doi.org/10.37547/iscrc-intconf15

\section{INTERNATIONAL SCIENTIFIC AND CURRENT RESEARCH CONFERENCES}

\author{
Hawaii USA \\ Crossref dot gil Google \\ Editor In Chief
}

Jared Keengwe, PhD,

Associate Professor, University of North Dakota, Department of Teaching \& Learning, 231 Centennial Drive STOP 7189, Grand Forks, ND 58202-7189, USA. 


\title{
SUPPORTING EDITORS
}

\section{S.S.A.Jafri}

School of Graduate Studies (Geography) Ethiopian Civil Service University, Addis Ababa, Ethiopia

\section{Dr. Erick Lusekelo Mwambuli}

Faculty of Accounting, Banking and Finance Institute of Finance Management (IFM), United Republic of Tanzania Qualification: PhD in Financial Management, Dongbei University of Finance and Economics

(DUFE), People's Republic of China

\author{
Dr. Victor Olu Matthews \\ Qualification: PhD (Telecommunication Engineering) \\ Affiliation: Senior Lecturer, Covenant University, Electrical \& Information Engineering \\ Department, Ota, Ogun State, Nigeria
}

João Simão,

Assistant Professor (Universidade Aberta and CAPP-Centre for Public Administration and Public Policies, Portugal)

Prof. Dr.

Angelo Emiro Paez Moreno (Universidad del Zulia, Venezuela)

Nicolae-Sorin Drăgan -

PhD in Communications Science, Collaborating Professor (Communication and Public Relations Faculty (FCRP) of the National University of Political Studies and Public Administration (SNSPA), Bucharest, Romania)

Alina Chervinchuk,

PhD student, Senior Lecturer at Journalism (Advertising and Media Communications chair Department of Journalism, Advertising and Publishing Odessa I. I. Mechnikov National University, Ukraine)

Dr. Tareq Nael Hashem,

Associate Professor of Marketing (Head of Marketing Department, Isra University, Jordan)

\section{Živilè Nemickienè,}

PhD. (Vilnius University; Kauno Kolegija/ University of Applied Sciences, Lithuania)

Dr. Maria Vaxevanidou (Press and Communication Councellor, Specialist in Public Diplomacy, Head of Directory of International Communication, Ministry of Foreign Affairs, Greece 
NO Author

1. Boymuradov Sh.A., Karimberdiyev B.I.

2. Gulchehra Sofiboyeva

3. Stela M. K.

4. Gulnoza Togaeva, Umid Akramov

5. Ravshan Tursunov

6. Pawan vashnav

7. Feruza Dzhambakieva

8. Nargiza Abdullaeva, Mahfuza Madaminova

9. Wang Ling

10. Shukhrat Shonazarov

11. Hasni Meon

12. Alisher Egamberdiyev, Ozodbek Nematov

13. Ali Husain Abbas

14. Bekzod Tolibov

15. Davronbek Raximov

16. Abdur Razzak

17. Dilshonjon Xakimov
FREQUENCY OF OCCURRENCE OF POSTTRAUMATIC SINUSITIS OF THE UPPER JAW (MAXILLA) IN PATIENTS WITH COMBINED FACIAL BONE INJURIES

DEVELOPING IMAGINATION ABOUT SPACE OF PRIMARY SCHOOL STUDENTS IN THE LEARNING PROCESS

EFFECT ASSESSMENT OF CHANGES IN THE ASSEMBLING LINE OF CYPROTERONE ACETIC ACID DERIVATION THROUGH EXAMINATION OF SIMILAR DISINTEGRATION PROFILE

NEW UNCONVENTIONAL VEGETABLE CULTURE AND PROSPECTS OF ITS DEVELOPMENT

COVERAGE OF THE ECOLOGICAL SITUATION IN TURKESTAN IN $19-23$ THE MEMOIRS OF SADRIDDIN AYNI

AN OVERVIEW PAPER ON EXTRACTION OF ASSESSMENT WORD AND ASSESSMENT FOCUS FROM ONLINE SURVEYS

LEGAL ANALYSIS OF NATIONAL LEGISLATION IN THE FIELD OF JUVENILE DELINQUENCY

SPECIFIC FEATURES OF ENGLISH AND UZBEK PROVERBS CONTAINING SIMILE

INTERREGIONAL THE TRAVEL INDUSTRY CHAIN ENHANCEMENT DEPENDENT ON FRAMEWORK ELEMENTS

EPIGRAPHIC MONUMENTS AS A HISTORICAL SOURCE ON THE HISTORY AND CULTURE OF THE KARSHI OASIS

THE EFFECT OF COACHING, THE BOARD BACKING AND PREPARING AND ADVANCEMENT ON THE REPRESENTATIVES' WORK EXECUTION

THE ROLE OF LARGE MARKETS IN THE LIFE OF THE COUNTRY DURING THE REIGN OF AMIR TEMUR AND THE TEMURIDS

ADVANCED PHONE HELPED LANGUAGE LEARNING

53-55

EVOLUTIONARY APPROACHES OF THE SOCIAL SERVICES

$56-59$ SYSTEM TO THE NECESSARY STAGES OF THE POPULATION

$60-64$

DETERMINED CRITERIA FOR DIVERSIFICATION IN INDUSTRIAL ENTERPRISES

PREDOMINANCE, ELEMENTS AND BRAIN RESEARCH OF $65-69$ SPOUSAL SAVAGERY IN BANGLADESH: A SIMILAR REPORT ON COUNTRY METROPOLITAN ATTRIBUTES

FORMATION OF MONEY TRANSMISSION MECHANISMS TO 70-74 INCREASE THE EFFICIENCY OF MONETARY POLICY 
18. Xianfa Cao

19. Hainun Nisa

20. Atakpu E Denni

21. Jordi Miro

22. Nodir Ruzimurodov, Tamara Aripova

23. Nodir Ortiqov, Obidjon Sayfiddinov
EXAMINATION ON THE SHOWING MODEL OF COLLEGE PC ESTABLISHMENT DEPENDENT ON MOOC MIXED LEARNING

CONCEPTUALIZING SCHOOL UPGRADES ASPECT INSIDE THE SETTING OF SCHOOL-BASED ADMINISTRATION

SYSTEMS OF POWERFUL DESIGNING PLANT UPKEEP AND ITS

84-86 SUGGESTIONS ON MODERN AND MONETARY DEVELOPMENT OF A NON-INDUSTRIAL COUNTRY

EVALUATION OF LEFTOVER BURDENS BECAUSE OF COLD

$87-90$ BOWING PRIMARY STEEL SUPPORTS UTILIZING LIMITED COMPONENT DISPLAYING

SOFTWARE PRODUCT FOR CLINICAL AND IMMUNOLOGICAL PROGNOSIS OF THE SEVERITY OF COVID-19

$91-93$

TRAFFICKING IN HUMAN BEINGS IS A TRANSNATIONAL CRIME 94-97 


\title{
FREQUENCY OF OCCURRENCE OF POSTTRAUMATIC SINUSITIS OF THE UPPER JAW (MAXILLA) IN PATIENTS WITH COMBINED FACIAL BONE INJURIES
}

\author{
Boymuradov Sh.A., \\ Tashkent Medical Academy Uzbekistan \\ Karimberdiyev B.I. \\ Tashkent Medical Academy Uzbekistan
}

ABSTRACT: Severe traumatic injuries are the third cause of death after cardiovascular and oncological diseases, and among people of working age it ranks first. People get severe combined injury in road accidents, in work-related injuries, in sports and natural disasters. According to the authors, $100 \%$ of patients with combined injuries of the bones of the facial skeleton have brain damage of varying degrees.

KEYWORDS: patients, neurosurgery, maxillofacial surgery, industrial injury, tomography examination, sinus epithelium, combined character.

MATERIAL AND METHODS. We examined $n=128$ patients with combined injuries of the bones of the facial skeleton (CIBFS) in the multidisciplinary clinic of the Tashkent Medical Academy in the department of neurosurgery, maxillofacial surgery and otorhinolaryngology in the period 2017-2020. The age of the patients ranged from 18 to 63 years, with 87 men and 41 women. All patients were admitted to the emergency department after an injury, they were given first aid and hospitalized in the department. Of the received $85.3 \%$ of the causes of injuries were road traffic injury, $7.2 \%$ had an industrial injury, $7.3 \%$ of patients had a sports injury. We conducted clinical and laboratory studies. The clinical examination included anamnesis of trauma, subjective and objective research methods. In addition, multispiral tomography of the paranasal sinuses, assessment of the condition of the nasal mucosa and the state of the natural excretory duct of the maxillary sinus, the state of motor activity of the atrial sinus epithelium in dynamics were performed.

RESULTS. The results of the study showed that 48 (76.3\%) patients out of 63 patients of this group had unilateral lesions of the maxillary sinus, 15 (23.7\%) had bilateral lesions. 2 (0.03\%) patients were on a ventilator for $5 \pm 1.1$ days. 


\section{PEDAGOGY AND MODERN EDUCATION: TRADITION, EXPERIENCE AND INNOVATION}

\section{Published: November 30, 2021 | Pages: 01-03}

Among the patients, $23 \pm 0.05$ had a fracture of the anterior rectus, $12 \pm 0.05$ a fracture of the upper rectus, $15 \pm 0.04$ a fracture of the lateral rectus, $5 \pm 0.02$ a fracture of the medial rectus. It should be noted that only $26 \pm 0.02$ (41.2\%) patients had isolated damage to only one wall, and in the remaining $37 \pm 0.03(58.8 \%)$ cases there were simultaneous damage to two, or combined damage to the walls of the sinus. In $12 \pm 0.05$ patients, pain in the suborbital region was noted. Nosebleed was observed in $39 \pm 0.04$ patients. A decrease in the sensitivity of the suborbital region was noted in $5 \pm 0.02$ patients. Diplopia was observed in $15 \pm 0.04$ patients. Nasal breathing disorders were observed in $23 \pm 0.05$ patients. Facial assimetry was noted due to subcutaneous hematoma of the soft tissues of the subglacial region on the affected side, The presence of a hematoma in the maxillary sinus was noted in $54 \pm 0.02$ patients, we determined in $100 \%$ of patients.

All patients underwent nasal cavity endoscopy on the first day after admission and diagnosis using multispiral computed tomography examination (MCTE). The endoscopy was performed with the Karl Storz endovideosystem. At the same time, the patency of the common nasal passages was assessed, the presence of bone-cartilage fragments, hematomas, fractures of the nasal septum, ruptures of the nasal mucosa was determined. In addition, the patency of the mouth was assessed. In 33 (52.3\%) patients, there was a pronounced violation of the patency of the maxillary sinus anastomosis, in 16 patients out of the total number, complete closure of the anastomosis was revealed.

CONCLUSIONS. Thus, the study showed that 69 (53.9\%) patients had unilateral lesions of the maxillary sinus, the remaining $59(46.1 \%)$ had bilateral lesions of the maxillary sinus. The most frequent type of fracture occurred in $26=0.03$ patients, followed by a fracture of the upper wall, which was in $22=0.06$ patients. Fractures of other walls are difficult to diagnose, they have a combined character. Fracture of the anterior wall of the maxillary sinus in most cases does not require surgical treatment.

\section{REFERENCES}

1. Камкин Е. Г. и др. Профилактика, диагностика и лечение новой коронавирусной инфекции (COVID-19) //Временные методические рекомендации. М.: Министерство Здравоохранения Российской Федерации. - 2020.

2. Мухамедова Н. С. Профилактика коронавирусной инфекции COVID-19//Новый день в медицине. - 2020. - №. 2. - С. 180-182. 


\section{PEDAGOGY AND MODERN EDUCATION: TRADITION, EXPERIENCE AND INNOVATION}

Published: November 30, 2021 | Pages: 01-03

3. Zukhritdinova, D., \& Nazarova, J. (2021). Clinical Structure of Headache Syndrome in Adolescents with Autonomic Dystonia Syndrome. European Journal of Molecular \& Clinical Medicine, 7(11), 4487-4493.

4. Janna, N. (2019). Cerebral hemodynamics in patients with cerebral venous dysfunction. European science review, 2(1-2).

5. Kurtieva, S., Nazarova, J., \& Mullajonov, H. (2021). Features of Physical and Generative Development of Modern Teenagers Living in Uzbekistan. NeuroQuantology, 19(7), 57.

6. Nazarova, J. (2021). Estimation of Clinical and Neurophysiological State of Cognitive Functions during Epilepsy in the Background of Anti-Consumer Therapy. International Journal Of Medical Science And Clinical Research Studies, 1(1), 01-04. 


\title{
DEVELOPING IMAGINATION ABOUT SPACE OF PRIMARY SCHOOL STUDENTS IN THE LEARNING PROCESS
}

Gulchehra Sofiboyeva

Basic Doctoral Student (PhD)

Namangan State University, Uzbekistan

\begin{abstract}
In this article, we have focused on the learning process of educators and learners. Objective: To study the current situation and the problem of improving the effectiveness of the study of geometric materials through the development of spatial imagination of primary school students in educational institutions. It's about finding the right solution to a problem.
\end{abstract}

KEYWORDS: imagination, spatial imagination, geometry, geometric materials, spatial shapes.

INTRODUCTION: The role of the child's imagination is enormous. Children because of their imagination they can easily remember the past, for example, if you tell a child the name of something that is not in front of his eyes, he will look around with his eyes and look for it [1]. Educational activity at the primary school age is a leading activity. Advanced thinking, including spatial imagination, is the basis for the development of cognitive processes and qualitative change, which in turn becomes the basis for success in educational activities. [2]

In "Developing the Spatial Thinking of School Students," I.S. Yakimanskaya gives the following definition: "Spatial thinking is a type of mental activity that allows the creation of spatial images and their operation in the process of solving various practical and theoretical problems" [3].

Through the child's perception of the environment, a spatial imagination is formed in him. Children begin to demonstrate spatial features by drawing and modeling. Their geometric spatial representation is evident through their drawings and models. One of the most effective ways to teach geometry is to do more practical work in teaching geometry in primary education.

In order to improve the quality of teaching geometry and mathematics, we focused on the learning process of teachers and students. We have studied the current situation in the study of geometric materials and increase their efficiency by developing the spatial imagination 


\section{PEDAGOGY AND MODERN EDUCATION: TRADITION, EXPERIENCE AND INNOVATION}

Published: November 30, 2021 | Pages: 04-08

of primary school students in educational institutions. During the observation, we received questionnaires from teachers and students. As a result, students do not fully develop general competence in geometric content. One of the main reasons for this is that students do not develop spatial imagination.

MATERIAL AND METHODS. Children have simple tasks to develop spatial imagination (Figure 1). Along with the teacher, parents have a big role to play in this task.

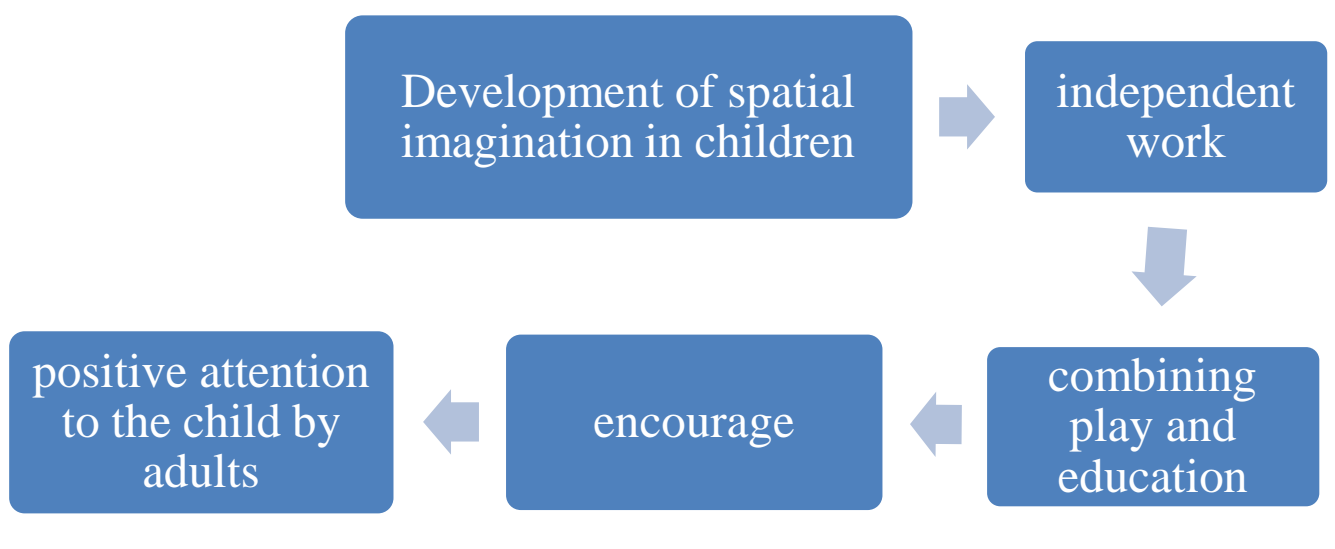

Figure 1. Tasks of developing spatial imagination in children

The tasks listed require a brief explanation. The tasks of developing spatial imagination are the study of geometric materials and the development of spatial imagination of primary school students.

As a result of the organization of experiments and observations, we can see that in the primary grades there is almost no introduction to geometric materials and practical training, limited only to the provision of theoretical knowledge. Proof of this is the fact that the questionnaires received from students were difficult to complete. The questionnaires in the questionnaire were grouped according to the SES requirements. In order to overcome these shortcomings and further develop our students 'geometric knowledge, we set up a team of teachers and planned a series of activities.

In order to improve the methodology of teaching geometric materials, we have identified the following "Tools used in teaching geometric materials" (Figure 2). The effective use of the above tools can be widely used in primary school to improve the mastery of geometric materials and increase the effectiveness of the lesson. 


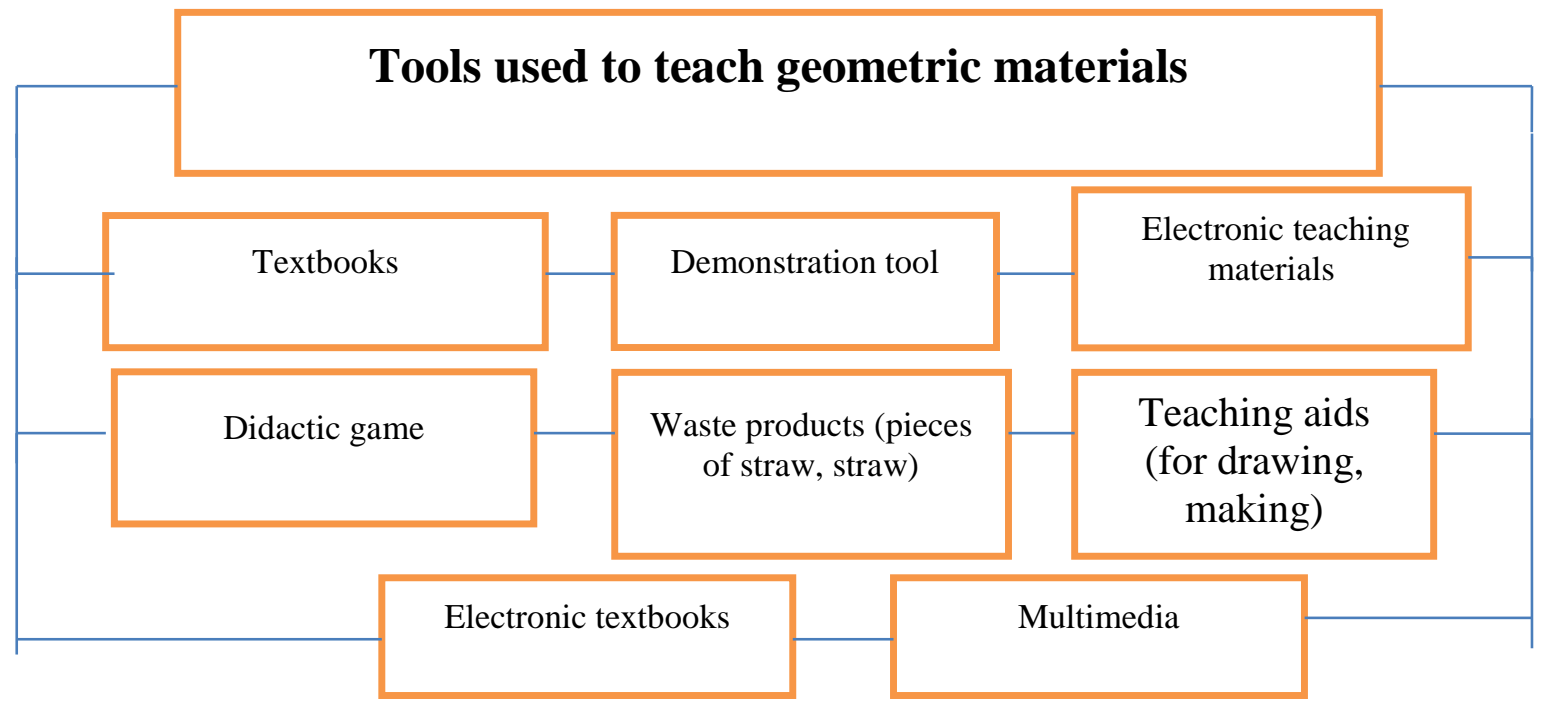

Figure 2. A tool module used to teach geometric materials.

Well-developed spatial perceptions in primary school can be a solid foundation for mathematical achievement in primary school and beyond [4].

Spatial perceptions develop and become stronger over time. As a result of the analysis of psychological and pedagogical literature, the approaches of scientists, educators and psychologists to this topic were studied, the features of the development of spatial imagination of primary school students were revealed[5-8].

CONCLUSION. The following pedagogical and psychological conclusions are appropriate:

- The work on the development of spatial imagination in students should be ongoing and systematic.

- Taking into account the learning activities of students in the planning of lessons and the use of didactic materials.

- Ensuring the use of a variety of methods and training to develop spatial awareness.

- Establish controls after spatial development exercises.

The spatial imagination formed during primary education is the most positive and effective. Therefore, we believe that textbooks should include as many materials and assignments as possible that develop geometric spatial imagination. 


\section{PEDAGOGY AND MODERN EDUCATION: TRADITION, EXPERIENCE AND INNOVATION}

Published: November 30, 2021 | Pages: 04-08

REFERENCES:

1. Z.Nishanova, G.Alimova "Child psychology and its teaching methods". Publishing House of the Literary Fund of the Writers' Union of Uzbekistan Tashkent - 2006. 58 p.

2. Батова А.А., Стойлова Л.п “ Особенности развития пространственного мышления” Педагогическое образование 2021, Том 2, №2 5 с.

3. Якиманская, И.С.Развитие пространственного мышления школьников. [Текст]/И.

С. Якиманская. - Москва: Педагогика, 1980. - 240 с.

4. Carr, M., Alexeev, N., Wang, L., Barned, N., Horan, E. and Reed, A. (2018), The Development of Spatial Skills in Elementary School Students. Child Dev, 89: 446-460. https://doi.org/10.1111/cdev.12753

5. Sofiboyeva, Gulchehra Mamurjanovna PhD (2021) "Developing pupils' logical thinking ability in the study of geometric materials in mathematics of primary schools," Central Asian Journal of Education: Vol. 6 : Iss. 1 , Article 1. Available at: https://uzjournals.edu.uz/cjedu/vol6/iss1/1

6. G. So'fiboyeva (2021) Improvement of the methodology of teaching geometric materials in primary schools. Public education, Scientific-methodical journal Ministry of public education of the Republic of uzbekistan. №6 Toshkent 2021. 59-63 p.

7. B.Sattarov, G.Sofiboyeva. (2020) "Ways to create logical thinking in primary school pupils. The Scientific Bulliten of Namangan State University 273-278.p

8. G.Sofiboyeva. "Use of integration technologies in the educational process". The Scientific Bulliten of Samarqand State University 2020. № 2

9. P.I.Ivanov, M.E.Zufarova "General Psychology". Philosophers of Uzbekistan Tashkent 2008. 183 p.

10. Jalilova S.X. "Psychology of preschool children." Philosophers Publishing House Tashkent - 2017. 355 p.

11. Barbashova, I. (2020), Formation of elementary school children's visual-spatial perception. Journal of interdisciplinary research ai.a.barbashova@gmail.com

12. Grades 1 to 3 Geometry and Spatial Sense. A Guide to Effektive Instruction in Mathematices. @ Queen's Printer for Ontario,2016 179 p. 


\section{PEDAGOGY AND MODERN EDUCATION: TRADITION, EXPERIENCE AND INNOVATION}

Published: November 30, 2021 | Pages: 04-08

13. Swoboda, E. Vighi, P. (2016) Early Geometrical Thinking in the Environment of Patterns, Mosaics and Isometries. ICME 13 Hamburg. http://www.springer.com/series/14352

14. Abramovich,S. Grinshpan,A. Milligan,D. (2019), Teaching Mathematics through Concept Motivation and Action Learning. Hindawi Education Research International, ID 3745406. https://doi.org/10.1155/2019/3745406

15. Linda Darling-Hammond, Lisa Flook, Channa Cook-Harvey, Brigid Barron \&David Osher (2019) Implications for educational practice of the science of learning and development. Applied Developmental Science DOI: 10.1080/10888691.2018.1537791 https://doi.org/10.1080/10888691.2018.1537791 


\title{
EFFECT ASSESSMENT OF CHANGES IN THE ASSEMBLING LINE OF CYPROTERONE ACETIC ACID DERIVATION THROUGH EXAMINATION OF SIMILAR DISINTEGRATION PROFILE
}

\author{
Stela M. K. \\ Professor, Federal University of Maranhão, Brazil
}

ABSTRACT: This work plans to assess the effect brought about by the difference in the tablet pressure machine in the assembling of $50 \mathrm{mg}$ cyproterone acetic acid derivation tablets, by inspecting the similar disintegration profile between various clusters of the medication. For this reason, the accompanying technique was utilized: the disintegration medium was made out of sodium dodecyl sulfate $0.07 \%$ in $0.01 \mathrm{M}$ hydrochloric corrosive, contraption II (paddle), paddle pivot at 100 cycles each moment, $900 \mathrm{~mL}$ volume of medium in every vessel, 37.50 .5 oC of medium temperature. Aliquots of $5.0 \mathrm{~mL}$ of test were gathered at 5, 10, 15, 20, 30 and 45 minutes. Then, at that point, the arrangements of the example and the norm $(50.5 \mathrm{~g} / \mathrm{mL})$ were assessed utilizing a spectrophotometer with frequency acclimated to $285 \mathrm{~nm}$. From this the near disintegration profile was plotted considering the medication rate broke up for each cluster in study as a component of the disintegration time.

KEYWORDS: imagination, spatial imagination, geometry, geometric materials, spatial shapes.

INTRODUCTION: A few creators concentrated on the impact of the compaction cycle boundaries on the granule properties. Different creators researched the impact of the compaction power on tablet strength of a sustainedrelease tablet and observed that the compaction power significantly affected the tablet hardness. The retention of a strong measurement structure after oral organization relies upon three factors: the arrival of the substance taken, the disintegration of the medication under physiological conditions and the porousness across the gastrointestinal parcel. Because of the basic idea of the initial two of these means, a vitro disintegration might be pertinent to the expectation of in vivo execution. In vitro disintegration testing is a monetary and helpful quality control instrument to viably guarantee adequate creation of tablets, cases and other strong measurement structures. 


\section{PEDAGOGY AND MODERN EDUCATION: TRADITION, EXPERIENCE AND INNOVATION}

Published: November 30, 2021 | Pages: 09-11

Disintegration is the cycle by which a strong solute enters an answer. In the drug business, it could be characterized as the measure of medication substance that goes into the arrangement per unit time under normalized states of fluid/strong interface, temperature and dissolvable structure.

Cyproterone acetic acid derivation is exceptionally solvent in dichloromethane. The free liquor is an enemy of androgen, the acetic acid derivation is both an enemy of androgen and a progestagen. The drug measurement structure is a progestational antiandrogen with intense antigonadotropic movement that outcomes in fast concealment of serum testosterone. Utilized as a solitary specialist, cyproterone acetic acid derivation yields a complete androgen bar. Cyproterone acetic acid derivation might manage the cost of transient objective improvement in patients not reacting to different types of chemical hardship. The medication might be utilized to stifle the hot flushes related with orchiectomy. Cyproterone acetic acid derivation actuates nearby cancer relapse; attributable to its reversible impacts, it is valuable as neoadjuvant or adjuvant androgen withdrawal treatment in patients with lower-stage sickness going through revolutionary medical procedure or radiotherapy.

MATERIALS AND STRATEGIES. Aliquots of $5.0 \mathrm{~mL}$ of test were gathered at 5, 10, 15, 20, 30 and 45 minutes. The measures of medication broke not set in stone in $1 \mathrm{~cm}$ quartz cells, utilizing a Bright/Noticeable Spectrophotometer, Thermo Logical (Advancement/201). Conclusions were completed against a clear disintegration medium. Tests and standard arrangements were ready in medium disintegration to get $50 \mathrm{~g} / \mathrm{mL}$ focus arrangements. The disintegration test utilized is a pharmacopeial technique [10] and was to some extent approved in our research facility. After the disintegration profile of 12 tablets from the principal pressure machine was assessed, the other 12 tablets were broke down similarly.

A changed item may likewise be a lower strength of a formerly endorsed drug item. Within the sight of specific minor changes, the single-point disintegration test might be sufficient to guarantee unaltered item quality and execution. For more significant changes, a disintegration profile examination performed under indistinguishable conditions for the item prior and then afterward the change(s) is suggested. Disintegration profiles might be viewed as comparable 


\section{PEDAGOGY AND MODERN EDUCATION: TRADITION, EXPERIENCE AND INNOVATION}

Published: November 30, 2021 | Pages: 09-11

by excellence of (1) in general profile likeness and (2) similitude at each disintegration test time point. The disintegration profile correlation might be done usingl free or ward model techniques.

CONCLUSION. In light of the similitude factor $\left(f_{2}\right)$ it is feasible to infer that the medications tried have comparative disintegration profiles freely of the tablet blower machine utilized in the assembling line. The disintegration effectiveness (D.E.) estimation exhibited that the distinctions acquired to the assembling lines are critical. In any case, the disintegration technique could be reexamined to examine appropriately the item in concentrate on utilizing discriminative conditions.

\section{REFERENCES}

1. Szalay I., Donng Xuan, K.D.T, Virág, Gy., Szentes, K.Á., Bódi, L. 2009: Prospects for conserving traditional poultry breeds of the Carpathian Basin. AWETH, 5 (2), 119-148.

2. Rea M. S, Figueiro M. G, Bullough J. D, Bierman A. 2005. A model of phototransduction by the human circadian system. Brain Research Reviews 2005, 50/2, 213-228.

3. Warburton, R.D.H., Wang, J. (2004). Analysis of asymptotic projectile motion with air resistance using the Lambert W function. American Journal of Physics. 72, 1404-1407.

4. Romero, C. \& Ventura, S., 2010, Educational data mining: a review of the state of the art. Systems, Man, and Cybernetics, Part C: Applications and Reviews, IEEE Transactions on, 40(6), 601-618.

5. Dong Xuan, K.D.T, Szalay, I., Su, V.V., Tieu, H.V., Vang, N. D. 2004: AnGR conservation strategies to develop low input mixed farming in South-East Asia. DAGENE Meeting, Bled (Slovenia, 2. September, 2004). 


\title{
NEW UNCONVENTIONAL VEGETABLE CULTURE AND PROSPECTS OF ITS DEVELOPMENT
}

\author{
Gulnoza Togaeva \\ Trainee Researcher, Tashkent State Agrarian University, Uzbekistan \\ Umid Akramov \\ Candidate of Agricultural Sciences, Associate Professor \\ Department of Vegetable Growing \\ Tashkent State Agrarian University, Uzbekistan
}

\begin{abstract}
The article provides information on the importance, use and nutritional value, origin, distribution and taxonomy, morphological characteristics and requirements for growing conditions of Japanese cabbage in scientific sources.
\end{abstract}

KEYWORDS: morphology, mibun, mizuna, profitability, decorative leaf, genotype, microelement, taxonomy.

INTRODUCTION: Food security depends on a range of socio-economic, demographic and environmental factors and is a key component of a country's development. The state food security policy is developed and implemented in four components of food security (food availability, purchasing power, their use and sustainability).

Humanity enjoys only one hundredth of the world's flora, which includes about 350,000 species plants. At the same time, UN FAO experts predict that by 2050 the world's population will reach 10 billion people. This would require an increase in food production by at least $50 \%$ if current consumption levels were maintained, although the United Nations estimates that 500 million people are already starving and 2 billion are undernourished.

With the growth of the population, the problem of high-quality nutrition is becoming more and more urgent. An important role in solving this problem is played by vegetables, which are not only highly productive and nutritious, but also have a special biochemical composition and are a very important source of vitamins, amino acids, mineral salts, carbohydrates and other valuable substances. 


\section{PEDAGOGY AND MODERN EDUCATION: TRADITION, EXPERIENCE AND INNOVATION}

Published: November 30, 2021 | Pages: 12-18

Man has always needed, needs and will need food. The consumption of nutrients is necessary for the normal functioning of his body. Healthy eating means eating a variety of foods in a balanced and acceptable amount $[2,7]$.

\section{THE MAIN FINDINGS AND RESULTS}

Vegetables provide $88 \%$ of dietary energy and $80 \%$ of protein. In addition, each plant species has a unique combination of biologically valuable components, and only a variety of large species can satisfy the need for "healthy plant food" [2]. The "regulatory framework for agriculture" should not only exclude contamination with pesticides, nitrates, mycotoxins, etc., but also ensure their biological (and aesthetic) usefulness. Essential amino acids, vitamins, mineral salts, taste [4].

Nature has endowed the land with a variety of vegetation. The flora of the Earth includes about 5,000 plants suitable for human consumption. About 600 vegetable plants are grown in all countries of the world, of which in Russia, as well as in Uzbekistan - only 70-80, belong to 12 families [4]. At the same time, for Uzbekistan and other CIS countries, there are traditionally 6 types of vegetable products (white cabbage, carrots, beets, onions, cucumbers and tomatoes), which provide about $90 \%$ of all marketable vegetable products [1].

The attraction of unknown and little-known plant species from local or foreign flora and new cultivated plants for growing from other countries constantly replenishes the vegetable assortment of many peoples of the world [2, 3, 4].

One of these unconventional vegetables is Japanese cabbage, a valuable vegetable and ornamental crop. Japanese cabbage leaves are eaten for their aromatic taste (some specimens have a characteristic sweetish taste).

Benefits and nutritional value of Japanese cabbage. The amount of vitamin $C$ is quite high, but it can be increased by slicing Peking cabbage pak choi [3]. The Mibun type is characterized by an increase in the content of chlorophylls A and B (3-carotene-6.0-6.4 mg / $100 \mathrm{~g}$ ) [1, 7]. Both varieties are rich in group B, vitamin PP, ash elements (1.1-1.3\%), including potassium, calcium, phosphorus, iron $[5,6]$.

A close relative of Japanese cabbage, Chinese cabbage is a source of longevity due to its existence. Lysine is an essential amino acid for the human body, has the ability to dissolve foreign proteins entering the human bloodstream, and is the main means of purifying the blood from harmful microbes and viruses, which increases the body's resistance to disease [6]. 


\section{PEDAGOGY AND MODERN EDUCATION: TRADITION, EXPERIENCE AND INNOVATION}

Published: November 30, 2021 | Pages: 12-18

However, there is no complete information on the biochemical composition of both varieties of Japanese cabbage, so it may be useful for further study. All this testifies to the importance of kale varieties and the prospects for their wider use in agriculture. [2, 4]

This is cabbage, which can be harvested at least twice in one growing season, which provides the population with fresh greens for a long time.

Origin, distribution and taxonomy of Japanese cabbage. The variety of Asian cabbage as a cultivated plant originated in central China. It was formed in Korea and is widespread especially in Japan, which is the secondary center of these cultures $[3,4,7]$. East Asian cabbage has been cultivated for a long time. Thus, Japanese cabbage has been known as a green and vegetable crop in China and Japan since the 16th century. However, among the cabbage, it is still the least known. It is grown mainly in Japan, China and the Pacific coast of Korea. Interest in this crop is growing and varieties can be found in catalogs of seed companies around the world. It is grown in Australia, Belgium, the Netherlands, Canada, Poland, the USA and other countries. The growing interest in this culture is associated with its therapeutic, prophylactic and nutritional properties.

According to the accepted classification, deciduous plants: Chinese cabbage, Chinese cabbage, Japanese cabbage and leafy turnip belong to Brassica rapa L. Japanese cabbage - Brassica rapa. var. Nippos (Bzassica campestris var. Japonica) is one of the least studied cabbage species. Originally from Korea and Japan. [7]

However, there is no consensus on the taxonomic position of Japanese cabbage. Thus, $G$. Olsson [3, 7] characterized this as a diversity (var.) of B. campestris species. Tsen Et Lee [2, 3, 5] counted the Japanese variety of Chinese cabbage (var. Japonica) B. ssp. chinensis; Siebold [3, 7], then L.N. Bailey [257] isolated it as a separate species B. B. japonica Sieb. sin. B. nipposinika Bailey. However, modern botanists generally follow the classification of G. Olsson, according to which Japanese cabbage belongs to the Brassica family, the Brassicaceae (Burnett) family, the Brassicaceae Hayek family, the Brassicaceae Hayek subtribe [3, 5, 6, 7].

Morphological features and growing conditions of Japanese cabbage. Morphologically, Japanese cabbage differs from other varieties of East Asian cabbage. The plant produces annual or biennial large-leaved rosettes (from 8-15 to 30) due to the awakening of many apical buds. This feature allows Japanese cabbage to grow back after being cut. In Japan, a fresh crop can be harvested within 50 days of mowing. The rosette is very decorative, medium. Leaves 


\section{PEDAGOGY AND MODERN EDUCATION: TRADITION, EXPERIENCE AND INNOVATION}

Published: November 30, 2021 | Pages: 12-18

develop from 5-8 equivalent buds, petiolate, medium, lyre-pinnate, three-lobed, narrow and medium-wide, green, less often dark green, glabrous, pointed [1, 7]. The multi-stemmed formation was probably caused by a mutation and revealed a sharp morphological difference between Japanese cabbage and related species. Japanese cabbage tends to form roots. Roots are conical, very large (length $8-12 \mathrm{~cm}$, diameter 5-7 cm), white, thin, dense, tastes like rutabaga.

In the conditions of the Leningrad region, Japanese cabbage is usually resistant to growth retardation. With early spring planting, some plants grow back after $75-85$ days and bloom in the first year of life.

There are two different forms of Japanese cabbage: long leaf mibun and mizunali. - Leaves are oddly leafy, this form is prone to root vegetables. Cabbage grows slightly slower than Peking and Peking cabbage, both types have a growing season of 90-100 days. In many morphological features, the shape of the scales is similar to salad mustard. Mizuna is very common in Japan, Mibuna is indigenous (Mibu is a region in Kyoto). The average weight of one Mibun plant outdoors is $0.6-0.9 \mathrm{~kg}$, and the average weight is $0.8-1.5 \mathrm{~kg}$. Productivity in greenhouses is $3-5$ $\mathrm{kg} / \mathrm{m} 2$ [4]. However, in the context of the Moscow region, there are no data on the yield and biochemical composition of two forms of cabbage, which have not been morphologically described and studied. Japanese cabbage is also an annual ornamental deciduous plant. The shapedly carved curly leaves of Japanese cabbage are painted in different colours at the end of July, have full decorative effect at the end of August and are stored until the onset of cold weather. It can be used to create curbs and decorate flower beds in gardens.

Requirements for the length of the day. Like other types of Japanese cabbage, East Asian cabbage species (especially Japanese) are long-lived plants. With a day length of 15-17 hours, the formation of generative organs is accelerated, and the formation of vegetative organs is inhibited and vice versa, when the length of the day is reduced to $15^{-13} \mathrm{~h}$, the transition to reproductive development in plants is delayed [2, 3, 4, 6, 7]. However, in plants, the response to day length can vary depending on the genotype of the plant.

Temperature requirements. The temperature factor is one of the most important factors, since the timing and possibilities of growing vegetables in the open field depend on it [2, 3]. Temperature indicators include heat demand, the amount of heat required during the growing season (sum of temperatures), and the plant's ability to withstand adverse (extreme) 


\section{PEDAGOGY AND MODERN EDUCATION: TRADITION, EXPERIENCE AND INNOVATION}

Published: November 30, 2021 | Pages: 12-18

temperatures (cold resistance and heat resistance). Seeds can grow at a temperature of $+2 \ldots 3$ ${ }^{\circ} \mathrm{C}$, but in this case the process is very slow. The optimum temperature for growing East Asian cabbage seeds is $+18 \ldots 20^{\circ} \mathrm{C}$, while seedlings emerge in 3-4 days. At a temperature of $+25 \ldots 28$

${ }^{\circ} \mathrm{C}$, seedlings emerge quickly, but they can elongate, grow slowly and die [2].

With the appearance of the first true leaves in the next 6-7 years, the temperature is optimal with the slightest fluctuations. At temperatures above $27^{\circ} \mathrm{C}$, plants are said to be highly attacked by fungal and bacterial pathogens [1].

The best temperature during the Socket period is $+18 \ldots 22^{\circ} \mathrm{C}$. Low temperatures in the range of $+4 \ldots 5^{\circ} \mathrm{C}$ for two to four weeks (depending on the genotype) and the next day at high temperatures are ideal for rapid growth plants.

The average temperature is $+12 \ldots 21^{\circ} \mathrm{C}$ with a short or average day length, which is favorable for the formation of the vegetative mass of the plant $[2,3,4]$. Mustard oil has been found to accumulate in crops at high temperatures and can affect taste [2].

Based on the above, it can be assumed that this is due to the cold resistance and simplicity. Japanese cabbage is successfully grown in the Tashkent region (indoor and outdoor). The cold resistance of seedlings depends on the degree of hardening and growing conditions. Frozen seedlings in pots with $5-8$ leaves can withstand temperatures up to $-5 \ldots 7^{\circ} \mathrm{C}$, and unfrozen seedlings are severely damaged by frosts up to $-2 \ldots 3^{\circ} \mathrm{C}[2]$.

Requirements for the water regime. Japanese cabbage belongs to the group of the most demanding vegetable crops in terms of its morphological characteristics: its root system is not very strong, and large leaves have a large evaporation surface. Especially hygrophilous Asian species, incl. and Japanese cabbage. The highest yield of these varieties of Japanese cabbage is achieved when soil moisture is in the range of $60-85 \%$ of the total moisture. A good supply of moisture not only increases the yield of these crops, but also accelerates their ripening under favorable temperature conditions [7].

Irrigation is recommended. Japanese cabbage is rare, but abundant. Watering at the root (along the groove) is desirable, because the leaves of this culture do not have a wax coating like white, and they are very thin.

Plant water resistance. In many areas, plant growth and development are subject to biotic and abiotic stresses, including. lack of water, increased soil salinity, high or low temperatures, etc. [5]. In the works of Wang and his colleagues [3], it is argued that the loss of crop yield under 


\section{PEDAGOGY AND MODERN EDUCATION: TRADITION, EXPERIENCE AND INNOVATION}

Published: November 30, 2021 | Pages: 12-18

the influence of abiotic factors can be up to 30\% in the next 25 years and up to 50\% by 2050 . Plant resistance to environmental stresses, including water shortage, is one of the tasks of many areas of crop production - genetics, physiology, biochemistry and breeding. Under conditions of water deficit, significant changes occur in plant metabolism, both in the concentration of individual compounds and in the degree of participation in the metabolism of individual enzyme systems. According to the literature, stress can lead to an increase in the content of soluble substances with osmotic potential. There are two ways to increase the viability of plants under conditions of high osmotic pressure (lack of water in the soil): by physiological adaptation of plants to this stress, or by changing the genotype of the population during the selection process.

Requirements for soil and fertilizers. Japanese cabbage grows well on fertile, moderately sandy, rather moist soils and effectively responds to the introduction of organic and mineral fertilizers into the soil [2].

In addition to the main elements, for the normal growth of Japanese cabbage, microelements are needed: boron, molybdenum, copper, magnesium and others [5, 7]. E.P. Shirokov [2] some trace elements not only increase the yield of the extract, but also accelerate its ripening, improve its chemical composition. I.A.Babichev [5] points out that fertilizers have a great influence on the correct combination of nutrients when they are correlated with the needs of the plant at different stages of growth and development. Nutrient requirements differ depending on the age of Japanese cabbage. Thus, during the growing season, he needs a balanced diet that is readily available with all the essential nutrients. After planting seedlings in the ground, to restore the root system and build an assimilation apparatus, the plant needs more nitrogen, and with the rapid growth of the leaf mass, more phosphorus and potassium [96].

CONCLUSION. In the Tashkent region, the reaction of plants to the temperature regime can be different. This situation requires a careful study of the vegetable crop.

\section{REFERENCES}

1. Artemieva A.M. New varieties of Chinese and Japanese cabbage selected by the All-Russian Research Institute of Plants. // IV International Symposium "New and unconventional plants and prospects for use" - M., 2001. - T.2. - S. 38-40. 


\section{PEDAGOGY AND MODERN EDUCATION: TRADITION, EXPERIENCE AND INNOVATION}

Published: November 30, 2021 | Pages: 12-18

2. Balashova Kh.Kh., Ignatov A.N. Use of genetic resources of the Brassicaceae family for breeding vegetable crops for disease resistance. - 1996.-№5.-C.20-26.

3. Boos G.V., Dzhokhadze T.I. The global cabbage gene pool and the use of the ego in breeding. // Sources of economically valuable traits for use in breeding vegetable and melon crops: collection of scientific papers on applied botany, genetics, breeding. - L., 1988. - T. 118. - S. 3-9.

4. Bunin M.S. New vegetable culture in Russia. - M .: FGNU "Rosinformagroteks", 2002. - 407 p.

5. Bunin M.S. Vegetable growing in Japan. - M., 1991 -- 55 p.

6. Bunin M.S. New vegetable culture in Russia. - M .: FGMU "Rospormagroteks", 2002. - 408s.

7. Ignatov A.N. Using fast-growing plants Brassica oleracea and Brassica rapa as model objects for studying the genetics of cabbage vegetables. // II-nd International Symposium "New and non-traditional plants and prospects for practical use": materials of reports. - Pushchino, 1997. T.4.-C.308-309. 


\title{
COVERAGE OF THE ECOLOGICAL SITUATION IN TURKESTAN IN THE MEMOIRS OF SADRIDDIN AYNI
}

\author{
Ravshan Tursunov \\ Candidate of Historical Sciences, Associate Professor at \\ National University of Uzbekistan named after Mirzo Ulugbek, Tashkent, Uzbekistan
}

\begin{abstract}
This article examines the ecological situation in Bukhara and the sand and dust storms that occurred in the second half of the 19th century which was described in a memoir written by Sadriddin Ayni.
\end{abstract}

KEYWORDS: Nature, ecology, natural disaster, weather, wind, sand and dust storms.

INTRODUCTION: Human life is directly related to nature and the events happening in it. Therefore, it is important for people to use natural resources wisely and take care of it properly. It is known from history that, as a result of the violation of the laws of nature, humanity has faced a whirlwind of great difficulties. Every action taken on nature in the pursuit of material gain has had its negative impact on the natural environment.

In the second half of the 19th century, the khanates in Turkestan, and later the Russian Empire, did not use the region's natural resources wisely, could not protect the flora, and failed to take into account water shortages, leading to environmental problems and various natural disasters, including sandstorms.

In his memoirs, Sadriddin Ayni, one of the leading figures of the Jadid movement in Bukhara assessed the ecological situation in the country and wrote about sand and dust storms in Bukhara. He witnessed this natural phenomenon and described in detail the damage it caused to nature and the socio-economic life of the population.

In ancient times, according to Ayni, when the Jilvan and Shofirkom rivers in Shafirkom district were wet, the village of Mahallai Bolo, where he spent his youth, was very prosperous. He wrote that the village of Mahallai Bolo came into a very bad condition as a result of the sand flooding of the Jilvan river and the old river of Shofirkom under the influence of sands that 


\section{PEDAGOGY AND MODERN EDUCATION: TRADITION, EXPERIENCE AND INNOVATION}

\section{Published: November 30, 2021 | Pages: 19-23}

later migrated from the Kyzylkum deserts. He described the ecological situation and problems in the village as "this village was like that as far as I remember myself"[1].

\section{THE MAIN FINDINGS AND RESULTS}

Due to the fact that many lands of Mahallai Bolo village had been covered with sand, the population in these areas faced great difficulties in farming and animal husbandry. As a result of the natural disaster, the arable lands in the villages of Shafirkom district were noticably reduced, which were also mostly in the hands of the rich.

In one of his childhood memories, he talked about his yard and village gardens, nature, apricot blossoms and also described how rural farmers were engaged in landscaping work, such as plowing land for farming, digging ditches and opening vineyards buried in vineyards.

In the memoirs, Ayni wrote that once with the permission of his father, he went out oofhis house, to join his brother, who was grazing sheep on the hills by the old river of Shafirkom. Along the way while he was going over the hill where his brother had been grazing sheep, he depicted the nature that was a greenery by the river. Together with his brother, he picked mushrooms on the hills. "At that moment," Ayni writes, "the wind began to blow and the air began to deteriorate. By the time we reached the bank of the river, the wind had intensified and covered the air with dust ... The wind became more and more intense, the sky was getting darker and darker. There was no trace of the greenery I had seen on the way ... The sand falling from the air turned the earth into sand dune in one breath. Even though people closed the doors and turned on the lights, the sand entered the house through the cracks of the doors and covered the beds ..." [3]

He wrote that the weather improved when he went out to the yard in the morning, but the yard and the garden turned into a sandy field, the flowers of the apricot trees were damaged, and the vines in the vineyards were covered with sand. The population carried out hashar works to eliminate the damage caused by this natural disaster, to clear the vineyards from under the sand.

He wrote that he went with his father to the village of Qoqoyavoni, where his grandfather lived, in order to give a hand in hashar works. He described that his father helped his 


\section{PEDAGOGY AND MODERN EDUCATION: TRADITION, EXPERIENCE AND INNOVATION}

\section{Published: November 30, 2021 | Pages: 19-23}

grandfather clear the orchards and vineyards of sand, noting that the village Qoqoyavoni had been considered to be more wet than the village of Mahallai Bolo, but as a result of the migration of sand, the place became a desert.

Sadriddin Ayni described the actions of the villagers as they tried to avert the damage: "In the fields, people were spread like grasshoppers: on the northeast side of the vineyards and orchards, they build barriers with branches and block the sand road. They would carry the sand on the vines and crops with shovels and sacks and take them to a place where the sand would not be harmful"[4].

In his memoirs, he wrote that he passed through the village of Boloi Rud on the way home, and that the natural disaster there also caused great damage. The author noted that this village, which had more wetlands and mills than other villages, was completely covered with sand, "although from time to time the roof corners of some high courtyards are visible, the village has lost its rural character and has a sandy desert landscape" [5].

Ayni's uncle, who returned from Tezguzar village in the days of the disaster, described to his father the damage caused by the sandstorms: "The gardens and orchards of the villages of Baghi Afzal and Tezguzar, the orchards of Karayogoch village, the northern part of Dehnavi Abdullajon, part of the village of Muhammad Boki and the village of Kochikhorlon are completely covered with sand. It is said that the sand attack reached the fortresses of Sayidato and Vardonze. "[6]

Life in Mahallai Bolo and other villages becomes much more difficult after the river is flooded by a sandstorm. He noted that there were few pools in the village. "After the sand flooded the village, it became completely thirsty, the pools dried up, and the water level in the wells decreased day by day. Shafirkom district was left without water ... Seeing this, my father moved us to Soktare as soon as possible "[7].

It should be noted that the people who left their lands due to the natural disaster in Shofirkom district returned to their villages, dug ditches filled with sand and tried to get water there, but the ditch was flooded with sand again, forcing the people to ask for help from the government to dig new canals. Excavation of the new canals needed to be carried out with the permission 


\section{PEDAGOGY AND MODERN EDUCATION: TRADITION, EXPERIENCE AND INNOVATION}

\section{Published: November 30, 2021 | Pages: 19-23}

and control of the government. Residents of the district asked the Emir for permission to dig a new canal, assuming all the labor and costs for the development of their territory. Ayni's memoirs contain the following information: "Emir Muzaffar sent an order to the khakim of Shafirkom district - judge, chairman, landowner and constable to start this work. The governors set to work after identifying the sites for the new canal. [8] In the meantime, the Emir sent a decree to the judge to go to Shafirkom and supervise the digging of a new canal. "[9]

As a result of the hard work of the population, in the autumn of the year when the hashar had begun, the digging of the canal was completed and the farmers started farming. The farmers of Shafirkom later cleaned the old riverbed from the sand by hashar without government intervention and poured some water from the new canal into it. As a result, the population restored the sandy lands and turned them back into greenery.

Based on the above information, it can be seen that these memoirs of Sadriddin Ayni are a very valuable source in the study of the ecological situation and problems in the Turkestan region. The author's description of almost all the events that took place during his life, including the sandstorm that took place in his village in his childhood, allows us to adequately understand the ecological situation and problems in the country during the period under study. It is also clear from the author's opinion that the residents of Shafirkom district, who abandoned their territories as a result of the natural disaster, were able to unite and save their homes from harm and turn them into a prosperous place. Had Ayni's other contemporaries recounted natural phenomena in their lifetimes, it would have served as an important source in the study of the history of nature and the environment of the region.

During the study of the ecological situation in the Turkestan region in the second half of the XIX century, it can be seen that a number of natural disasters, including sand and dust storms, occurred as a result of human inefficient use of natural resources.

CONCLUSION. There are several reasons for this, firstly, the fact that the khanates, which cover large areas, focus on nature conservation in the central regions, giving almost no attention to the ecological situation in remote areas, deserts and steppes, and secondly, the population in these areas often used firewood of various trees and plants as fuel causing great damage to the flora of these areas which resulted the desert sands changing their location under the 
Published: November 30, 2021 | Pages: 19-23

influence of strong winds, and thirdly, the lack of interest in the study of modern science in the khanates, khans or emirs, knowing that there are mineral resources in their territory and did not know how to use it effectively, including oil fields, the population often used various trees and plants as fuel and, fourthly, the Russian Empire used natural resources aggressively turning the country into a raw material base.

\section{REFERENCES}

1. Sadriddin Ayni. Works. Memories. Part I-II. T.5. - Tashkent, 1965. - P.17.

2. Alimova D. History as history, history as science. T. 2. The phenomenon of Jadidism. Tashkent: Uzbekistan, 2009.

3. Sadriddin Ayni. Works. Memories. Part I-II. T.5. - Tashkent, 1965. - P.23.

4. Sadriddin Ayni. Works. Memories. Part I-II. T.5. - Tashkent, 1965. - P.25.

5. Tursunov R. Ecological condition and mysteries in Turkestan periodical press in the early XX century (in the case of Sadoi Fergana newspaper) // ISJ Theoretical \& Applied Science, Philadelphia, USA. 2019, 05 (73), - P. 570-574.

6. Sadriddin Ayni. Works. Memories. Part I-II. T.5. - Tashkent, 1965. - P.29.

7. Sadriddin Ayni. Works. Memories. Part I-II. T.5. - Tashkent, 1965. - P.68.

8. Sadriddin Ayni. Works. Memories. Part I-II. T.5. - Tashkent, 1965. - P.71. 


\section{AN OVERVIEW PAPER ON EXTRACTION OF ASSESSMENT WORD AND ASSESSMENT FOCUS FROM ONLINE SURVEYS}

\section{Pawan vashnav \\ Department of Computer Engineering, CEK-College of Engineering Kopargaon, India}

ABSTRACT: Assessment mining is only mining assessment targets and assessment words from online surveys. To track down assessment connection among them to some extent managed word arrangement model have utilized. To observe certainty of every competitor chart based co-positioning calculation have utilized. Further up-and-comers having certainty higher than edge esteem are separated as assessment word or assessment targets. Contrasted with past approach sentence structure based technique this strategy can give right outcomes by wiping out parsing blunders and can chip away at audits in casual language. Contrasted with closest neighbor strategy this technique can give more exact outcomes and can track down relations inside a long range. Likewise to diminish mistake proliferation diagram based co-positioning calculation is utilized to by and large concentrate assessment targets and assessment words. Likewise to diminish likelihood of mistake age entrance of serious level vertices is done and decline impact of irregular walk.

KEYWORDS: Assessment mining, assessment words, assessment target, to some extent regulated word arrangement model, coranking calculation, word arrangement model.

INTRODUCTION: Assessment target is only the item with respect to which assessment is given and assessment word are words which express client assessment. In above model "screen" and "LCD goal" are assessment targets and "vivid" "huge" and "baffling" are assessment words. Past strategies use Bootstrapping which together concentrate assessment target and assessment word for example "beautiful" and "large" alter screen in wireless space and they have assessment connection then, at that point, assuming we realize that bright is assessment word then we can remove screen as assessment target and from screen target we can extricate large as its viewpoint word. Impediments of this methodology is that Closest neighbor rule remove assessment word and focus inside a restricted window just anyway if there should arise an occurrence of Syntactic example downside is that it can't give right 


\section{PEDAGOGY AND MODERN EDUCATION: TRADITION, EXPERIENCE AND INNOVATION}

Published: November 30, 2021 | Pages: 24-27

outcomes when audits are in casual composing having linguistic mistakes and typographical blunders. Aggregate extraction utilized by most Bootstrapping techniques has issue of blunder proliferation. To eliminate such disadvantages this paper has utilized Word arrangement model to mine connection between assessment word and target.

To dispense with the issue of mistake engendering they have utilized diagram co-positioning for that they have developed assessment connection chart which models all assessment word or target and assessment relations among them. Further to appraise applicants trust in a diagram they have utilized irregular walk based co-positioning calculation. At last applicants with higher certainty than edge are separated. For chart co-positioning cycle they have expected all things/thing phrases as assessment target and descriptor/action words as assessment words. They have utilized monolingual word arrangement model to catch assessment relations likewise moreover utilized somewhat managed word arrangement model. Further they have utilized irregular co-positioning calculation to fine certainty of every competitor. They have utilized not many imperatives to stay away from immaterial arrangement, for example,

1) thing/thing phrases should line up with modifier/action words or the other way around. Line up with Invalid means word alters/changed by nothing.

2) Other disconnected words for example combination, relational words and intensifiers line up with themselves.

GuangQiu, Bing Liu, Jiajun Bu, and Chun Chen, "Assessment Word Extension and Target Extraction through Twofold Spread": In this paper they have utilized rundown of assessment words for example assessment dictionary, since it's exceptionally difficult to keep up with general assessment vocabulary which covers all areas. Additionally same word in one space can be positive and in another area can be negative. They have utilized beginning seed assessment vocabulary so this technique is semi-managed. Likewise this methodology engenders data to and fro between assessment target and word so particularly known as twofold spread. In this new assessment target and words are extricated from input assessment dictionary and 


\section{PEDAGOGY AND MODERN EDUCATION: TRADITION, EXPERIENCE AND INNOVATION}

Published: November 30, 2021 | Pages: 24-27

engendering proceeds till no new assessment words and target present. They have utilized assessment word dictionary and audit information as contribution to engendering calculation, likewise utilized some predefined spread standards dependent on relations for assessment target extraction. Further utilizing assessment target pruning wrong assessment targets and words are taken out.

K. Liu, H. L. Xu, Y. Liu, and J. Zhao, "Assessment target extraction utilizing somewhat managed word arrangement model,": In this paper they have utilized to some extent directed word arrangement model (PSWAM) in monolingual situation which mines assessment relations in sentences. Further they have utilized co-positioning calculation on chart to observe certainty of every up-and-comer and extraction of competitor having higher certainty is done as assessment target. Contrasted with past grammar based strategies PSWAM gives better outcome by trying not to parse mistakes in casual sentences in internet based surveys.

CONCLUSION. In this paper we concentrated on various Assessment Word and Assessment Target extraction procedures from online surveys. Our plan utilizes to some degree regulated word arrangement model to further develop arrangement quality by utilizing piece of connections of completely adjust sentence as requirement to arrangement model. Contrasted with past techniques closest neighbor and syntactic example strategy proposed strategy kill the greater part of disadvantages and give better outcomes. By utilizing diagram co-positioning strategy proposed framework can observe certainty worth of every applicant and can observe right assessment words and target. In future work is to utilize more development relations between assessment word and assessment focus for instance effective relations which will assist with observing more accurate assessment words and focuses from online audits.

\section{REFERENCES}

1. Zhangjie Fu, Xingming Sun, Nigel Linge and Lu Zhou, “Achieving Effective Cloud Search Services: Multikeyword Ranked Search over Encrypted Cloud Data Supporting Synonym Query", IEEE Transactionson Consumer Electronics, Vol. 60, No. 1, February 2014.

2. Qin Gao, Nguyen Bach and Stephan Vogel, "A Semi-supervisedWord Alignment Algorithm with Partial Manual Alignments", 2010. 
Published: November 30, 2021 | Pages: 24-27

3. T. Jenn-Yue, H. Yajun, and T. Chen-Khong, "Interference-minimized multipath routing with congestion control in wireless sensor network for highrate streaming," IEEE Trans. Mobile Comput., vol. 7, no. 9, pp. 1124-1137, Sep. 2008.

4. Lei Zhang,Bing Liu,Suk Hwan Lim and Eamonn O’Brien-Strain “Extracting and Ranking Product Features in Opinion Documents" 2011.

5. Mr. A. V. Moholkar, Prof. S. S. Bere, “Identification of Features from User Opinions using Domain Relevance," International Journal on Recent and Innovation Trends in Computing and Communication, June 2015. 


\section{LEGAL ANALYSIS OF NATIONAL LEGISLATION IN THE FIELD OF JUVENILE DELINQUENCY}

\section{Feruza Dzhambakieva}

\section{Lecturer, Department of "State and Legal Disciplines" Specialized Branch of Tashkent State} Law University, Uzbekistan

ABSTRACT: The article offers a general overview of the national legislation in the field of combating juvenile delinquency. Ongoing reforms in this area. The role of the state in the prevention of offenses, which consists in the implementation of a set of interrelated measures carried out by bodies and institutions directly engaged in the prevention of offenses in order to preserve and strengthen law and order, identify, suppress offenses, as well as identify, eliminate the causes of offenses.

KEYWORDS: offense, juvenile delinquent, neglect, homelessness of minors, antisocial actions, prevention, misconduct, criminal liability, administrative responsibility, disciplinary responsibility, civil liability, regulatory framework.

INTRODUCTION: The problem of juvenile delinquents in today's society is one of the most complex and controversial. Unfortunately, not every teenager is aware of what illegal acts they commit lead to severe and difficult-to-fix consequences. One of the main directions of the policy of any democratic state is the prevention of offenses, which consists in the implementation of a set of interrelated activities carried out by bodies and institutions directly engaged in the prevention of offenses in order to preserve and strengthen law and order, identify, suppress offenses, as well as identify, eliminate the causes of offenses and conditions conducive to them.

Subsequently, in order to regulate relations in the field of prevention of neglect and delinquency among minors, the Law of the Republic of Uzbekistan No.-263 "On prevention of neglect and delinquency among minors" was adopted on September 29, 2010, which defined a system of social, legal, medical and other measures aimed at identifying and eliminating the causes and conditions conducive to neglect, homelessness of minors, their commission of offenses or other antisocial actions, carried out in conjunction with individual preventive work. 


\section{PEDAGOGY AND MODERN EDUCATION: TRADITION, EXPERIENCE AND INNOVATION}

Published: November 30, 2021 | Pages: 28-31

THE MAIN FINDINGS AND RESULTS. The following legislative normative legal acts in this area are the Law of the Republic of Uzbekistan dated May 14, 2014 "On the prevention of offenses", the Law of the Republic of Uzbekistan dated September 16, 2016, Law No. 407 "On internal Affairs bodies", the Decree of the President of the Republic of Uzbekistan dated March 14, 2014 PP-2833 "On measures to further improve the system of crime prevention and combating crime". Thus, at the legislative level, the legal basis for the prevention of neglect and delinquency only among minors has been defined. This circumstance, as well as the need to implement priority tasks to improve legal mechanisms that ensure public order, protect the rights and legitimate interests of citizens from criminal encroachments, pointed to the need for further improvement of legislation in the field of general crime prevention.

It is necessary to briefly give a definition of the concept of offense. An offense is the guilty behavior of a legally capable person, which contradicts the prescriptions of the norms of law, causes harm to other persons and entails legal responsibility. All offenses are usually divided into two groups: misdemeanors and crimes (the most serious offenses). Misconduct can be labor, disciplinary, administrative and civil (tort). Crimes are understood, as a rule, as criminal offenses, that is, acts that violate the criminal law. They may vary in severity category. Depending on the type of offense, appropriate responsibility is allocated - criminal, administrative, disciplinary, civil law. 1. Criminal liability - liability for violation of the laws provided for by the Criminal Code. A crime provided for by criminal law is socially dangerous, encroaching on the social order, property, personality, rights and freedoms of citizens, public order (murder, robbery, rape, insults, petty theft, hooliganism). For malicious hooliganism, theft, rape, criminal liability begins at the age of 14 .

2. Administrative liability is applied for violations provided for by the Code of Administrative Offences. Administrative violations include: violation of traffic rules, violation of fire safety. For administrative offenses, they are brought to responsibility from the age of 16 . Punishment: fine, warning, correctional labor.

3. Disciplinary responsibility is a violation of labor duties, i.e. violation of labor legislation, for example: late for work, absenteeism without a valid reason.

4. Civil liability regulates property relations. Penalties for the offender: compensation for harm, payment of damage. 


\section{PEDAGOGY AND MODERN EDUCATION: TRADITION, EXPERIENCE AND INNOVATION}

Published: November 30, 2021 | Pages: 28-31

Analyzing the regulatory framework for the prevention of juvenile delinquency, the main objectives of the prevention of neglect and juvenile delinquency are:

* prevention of neglect, homelessness of minors, their commission of offenses or other antisocial actions, identification and elimination of the causes and conditions that contribute to them;

* ensuring the protection of the rights, freedoms and legitimate interests of minors;

* formation of law-abiding behavior of minors;

* socio-pedagogical rehabilitation of minors and families in a socially dangerous situation;

* identification and suppression of cases of involvement of minors in the commission of offenses or other antisocial actions.

The basic principles of crime prevention include legality, humanity, consistency, priority of the method of persuasion and differentiation of measures of influence and an individual approach. The types of crime prevention have been established, which include general crime prevention, special crime prevention, individual crime prevention and victimological crime prevention.

The necessary conditions are being created in the country to ensure the rights and interests of young people, so that young men and women receive education, have a decent job, and can realize their knowledge and abilities. Practical confirmation of this was the announcement of 2021 as the Year of Youth Support and Public Health Promotion. President Shavkat Mirziyoyev's quote to the point: "Youth is the hope and support of the people, acts as a decisive force in the effective implementation of large-scale reforms. Undoubtedly, an important place in the further development of the country is occupied by young people who master modern knowledge and professions, innovative technologies, foreign languages."

As you know, young people tend to think in a new way, confidently propose and implement new ideas, and take an unconventional approach to solving problems. Therefore, today we attach priority to the quality education of the younger generation, the realization of their talents and potential in science, business, art, literature and sports, ensuring active participation in public and political life

CONCLUSION. Summing up the above, we can conclude that reforming the legislative framework in the field of juvenile delinquency is another step towards further deepening democratic reforms and the formation of a strong civil society in the country, will ensure the 


\section{PEDAGOGY AND MODERN EDUCATION: TRADITION, EXPERIENCE AND INNOVATION}

Published: November 30, 2021 | Pages: 28-31

formation of a holistic regulatory framework in the field of crime prevention, will further strengthen the rule of law in the country, the creation of an effective, multi-level system of crime prevention, ensuring the protection of public order, the protection of the rights and legitimate interests of citizens.

\section{REFERENCES}

1. Legal encyclopedia under the general editorship of Doctor of Law U.Tadzhikhanova Tashkent "Sharq" 2001/ pages 656

2. Ismailov I, Ziyodullayev. $M$ “Organization of activities and cooperation of prophylactics in the base units of internal affairs bodies." Educational-practical guide. Academy of the Ministry of Internal Affairs. 2017/ pages 130

3. The Law of the Republic of Uzbekistan No.-263 "On prevention of neglect and delinquency among minors" September 29, 2010

4. "On the prevention of offenses", May 14, 2014 


\title{
SPECIFIC FEATURES OF ENGLISH AND UZBEK PROVERBS CONTAINING SIMILE
}

\author{
Nargiza Abdullaeva \\ PhD, National University of Uzbekistan \\ Mahfuza Madaminova \\ 2nd course, master's degree, \\ UzSWLU, Uzbekistan
}

\begin{abstract}
This paper discloses the specific features of simile in proverbial contents of the English and Uzbek languages. Simile is frequently used in oral speech and fiction as one of the stylistic devices. Besides, it is also often faced in proverbs in both languages. Furthermore, proverbs including simile are analysed with the examples in English and Uzbek in this work.
\end{abstract}

KEYWORDS: stylistics, stylistic device, simile, proverb, paremiology.

INTRODUCTION: Stylistics, sometimes called "linguo-stylistics", is a branch of general linguistics. It has now been more or less definitely outlined. It deals mainly with two interdependent tasks: a) the investigation of the inventory of special language media which by their ontological features secure the desirable effect of the utterance and b) certain types of texts (discourse) which due to the choice and arrangement of language means are distinguished by the pragmatic aspect of the communication [Galperin, 2001: 9].

The two objectives of stylistics are clearly discernible as two separate fields of investigation. The inventory of special language media can be analysed and their ontological features revealed if presented in a system in which the co-relation between the media becomes evident. The types of texts can be analysed if their linguistic components are presented in their interaction, thus revealing the unbreakable unity and transparency of constructions of a given type. The types of texts that are distinguished by the pragmatic aspect of the communication are called "functional styles of language", the special media of language which secure the desirable effect of the utterance are called "stylistic devices" and "expressive means". 


\section{PEDAGOGY AND MODERN EDUCATION: TRADITION, EXPERIENCE AND INNOVATION}

Published: November 30, 2021 | Pages: 32-34

THE MAIN FINDINGS AND RESULTS. Stylistic device - a figure of speech based on a conscious and intentional intensification of some typical structural or semantic properties of a language unit that becomes a generative model designed to achieve a particular artistic effect [Ashurova, Galieva, 2013: 197].

One of the often-used stylistic device is simile. A simile is a phrase that uses a comparison to describe. It looks like metaphor in its sense. For example, "life" can be described as similar to "a box of chocolates":

Simile: Life is like a box of chocolates.

Metaphor: Life is a box of chocolates.

A simile is a type of figurative language that describes something by comparing it to something else with the words "like" or "as".

Similes are great for famous authors, public speakers, and folks who want to make their writing as exciting as a spontaneous show of fireworks. They are also often heard in proverbs.

Paremiology as the study of proverbs, saying, aphorisms, includes stylistic features of proverbs, too. Moreover, stylistic devices such as metaphor and simile enliven proverb's meaning and its stylistic potential in its content. For instance:

English: Like father, like son.

This proverb says that a son looks like to his father in many ways: in his appearance, character or behaviour.

Uzbek: Yaxshi gap ko'ngilni tog‘dek ko'tarar.

Translation: A good word rises one's soul as a mountain.

The proverb expresses that if you say a good word to someone, he or she will be delighted so much and his or her soul reaches a mountain in figurative way.

English: As busy as a bee.

In this proverb, hardworking people is compared with a bee in English culture.

Uzbek: Chumolidek mehnatkash.

Translation: As hardworking as an ant.

Here, in the Uzbek national proverb, hardworking people is compared with an ant.

The proverbs above-given in the English language are taken from J. Speake and J. Simpson's monolingual dictionary [Speake and Simpson, 2008] and the proverbs of the Uzbek culture are taken from N. Abdullaeva's bilingual dictionary [Abdullaeva, 2020]. 
CONCLUSION. To conclude, simile in proverbial structures emphasises the comparison among two things, notions, persons or events according to their resemblance, which intensifies the semantic strength and stylistic potential of the proverb. It is also the reason to remember the proverb containing simile very easily and to make them touchable in a context. Although both English and Uzbek national proverbs include similes in their contents, the compared things, notions, persons or events differ from one language to another as they belong to different cultures. The hardworking man is compared with a bee in English while he is compared with an ant in Uzbek culture relatively.

\section{REFERENCES}

1. Abdullaeva N. Dictionary of English and Uzbek National Proverbs Containing Graduonyms. - Mauritius: Lambert Academic Publishing, 2020.

2. Ashurova D.U., Galieva M.R. Stylistics of Literary Text. - Tashkent: Alisher Navoiy, 2013.

3. Galperin I.R. Stylistics. - Moscow: URSS, 2001.

4. Speake J., Simpson J. The Oxford Dictionary of Proverbs. Fifth Edition. - N.Y.: Oxford University Press, 2008. 


\title{
INTERREGIONAL THE TRAVEL INDUSTRY CHAIN ENHANCEMENT DEPENDENT ON FRAMEWORK ELEMENTS \\ WANG Ling \\ Teaching Faculty, College of Commerce and Management, China
}

\begin{abstract}
The improvement of transportation industry, space distance in time was incredibly abbreviated, the gigantic ascent of territorial the travel industry action in various space of the connection between the travel industry ventures of the undeniably close; In this specific circumstance, the current the travel industry tie is hard to adjust to the requirements of new circumstance, should be upgraded and rebuilding. In light of the foundation of interregional the travel industry chain, based on the advancement objective, utilizing framework elements technique, developed the interregional the travel industry chain enhancement model, and the model was tried and assessed.
\end{abstract}

KEYWORDS: the travel industry chain, framework elements, Enhancement; Interregional.

INTRODUCTION: As between local the travel industry in the modern economy can be considered as a travel industry chain expansion, this economy is called between provincial the travel industry chain, the improvement of between local the travel industry affix needs to go between ventures in various districts nearer cooperation. With the increment in the quantity of between provincial the travel industry deals, locale the travel industry chain set off crossterritorial between local collaboration in the travel industry endeavors in the opposition will confront regulatory hindrances to between local and interregional data unevenness, leading to the high exchange costs, will unavoidably turn into an imperative between local the travel industry chain, fast and sound improvement of the primary bottleneck. Nonetheless, this developing between territorial the travel industry affix because of the colossal range in space, making the travel industry as an association's current chain is hard to straightforwardly apply the above chain of between local the travel industry generated. In this specific circumstance, this review endeavors to concentrate on the overall association of the business chain content and nature, joined with the unique idea of between territorial the travel industry chain, the utilization of secluded hypothesis, provincial collaboration and rivalry hypothesis to the 


\section{PEDAGOGY AND MODERN EDUCATION: TRADITION, EXPERIENCE AND INNOVATION}

Published: November 30, 2021 | Pages: 35-39

hypothesis of between local the travel industry bind hoping to beat the regulatory boundaries and decrease authoritative chain of new types of hilter kilter data, so the between local the travel industry chain to accomplish economies of scale, profundity of division of work and the reason for lessening exchange costs.

Framework Elements was established in 1956 is a unique investigation and reproduction of perplexing frameworks science. Framework elements is a sort of design, capacity and history together, through PC displaying and recreation and quantitative investigation of the request, nonlinear, multi-input framework hypothesis and strategies for complex time-shifting frameworks, the hypothesis and techniques for economical improvement is a precise investigation of a fruitful and significant ways. It is the arrangement of science and the executives science in a branch, yet additionally a correspondence between the regular and sociologies disciplines horizontal, can be utilized for investigation of social, monetary, natural and organic complex framework issues. It joins frameworks hypothesis, robotics and data hypothesis in one, utilizing programmatic experience innovation, for the most part utilizing differential conditions or differential conditions to make a framework model for the arrangement and treatment of those higher-orders, nonlinear, time-fluctuating multi-criticism framework is an exceptionally powerful apparatus. Framework elements model can be utilized as the real framework, particularly the demonstrating system of social, financial, biological complex arrangement of "lab" framework elements is a learning cycle of examination, the principle capacity of the model is to furnish individuals with a direct investigation instrument for learning and navigation. As of now, the framework elements developing scope of uses, particularly to concentrate on amazingly complex full scale issues, for example, the improvement direction of the review region the framework, which involves regular assets, geological area, traffic conditions, relocation, ecological limit, venture and complex arrangement of exchange and different issues of shared relations.

TECHNIQUE. Between Territorial The travel Industry Chain Enhancement Objectives

The reason for this review to fabricate between territorial the travel industry affix improvement model is to wipe out between local the travel industry chain advancement deterrents, and consequently, the between local the travel industry chain streamlining objective is the coordination of this section for the advancement of between local hindrances 


\section{PEDAGOGY AND MODERN EDUCATION: TRADITION, EXPERIENCE AND INNOVATION}

Published: November 30, 2021 | Pages: 35-39

set up by the travel industry chain. As per resolve between provincial the travel industry chain advancement problems, this article wills between territorial the travel industry chain enhancement and coordination objectives credited to the accompanying angles:

1. further develop the travel industry structure;

2. making successful collaboration model to guarantee a reasonable dispersion of the advantages of the business chain;

3. expanding the assortment of the travel industry items, diminish horrendous contest.

Between Local The travel Industry Chain Streamlining and Joining Model Structure Thoughts

Framework in general, its general investigation is the initial phase in tackling the issue elements utilizing the framework, whose fundamental assignment is to dissect the issue, since you need to break down, recognize research purposes. It must be done include: overview gathered data about the framework's case and measurable information; comprehend the prerequisites of the exploration question, a reasonable reason and issues to be addressed; essential issue examination framework and the primary issue, the fundamental inconsistency with the foremost inconsistency, factors and the principle factors; starter delimitation framework and decide endogenous factors, exogenous factors, input; decide the conduct of the framework reference model. The principle errand of underlying examination of the framework is an input instrument to manage framework data, framework investigation, it needs to accomplish the primary work incorporates: investigation of the general framework and neighborhood criticism component; between the factors and examination framework; various leveled division framework with sub-block relationship, characterized factors (counting consistent), to decide the sorts and key factors; decide the criticism circle and circle coupling connection between; at first distinguished the framework's fundamental circuit and their properties; dissect the chance of the exchange of the primary circle over the long haul, At last, set up a normalized framework elements model. Between territorial the travel industry chain is an enormous framework, the intricacy and inconstancy of the genuine between provincial the travel industry chain chose not considered in the review between local parts of the business chain, and subsequently just the whole between local the travel industry chain framework reflection of the moderately helpless construction a "great" and which model to reproduce the design - work simple There 


\section{PEDAGOGY AND MODERN EDUCATION: TRADITION, EXPERIENCE AND INNOVATION}

Published: November 30, 2021 | Pages: 35-39

Dependent on this, all boundaries will expand the worth of the variable to 7 (where per capita discretionary cashflow and schooling levels stay the first worth), the working outcomes in the wake of changing boundaries were contrasted and the first information, tracked down that the region, providing food and convenience, the travel industry data stage, travel services, vacationer center, the requirements of sightseers, traveler fulfillment and dedication of travelers, the travel industry associations, between local the travel industry store network reconciliation profundity pointers between local the travel industry inventory network, offices and supporting associations, for example, the significant factors in the model is worth to a critical advancement. Between region travel from the streamlining and mix of modern chain model reproduction results, we tracked down that: when the first worth of the boundary to work on our model of the significant factors, for example, between provincial the travel industry store network combination profundity, the profundity of mix office, vacationer fulfillment and sightseers patterns steadfastness is superior to the first information under the recreation results.

CONCLUSION. Such outcomes recommend that: when to reinforce collaboration between the public authority, ventures and other vacation spots, can create higher and more successful than before supply proficiency, and the capacity to additionally further develop consumer loyalty and dedication sightseers, bringing about more noteworthy financial In the interim, when the instance of the travel industry associations all through the locale on the event of the travel industry chain more compelling administrative requirements, the whole chain of between provincial the travel industry to be more powerful turn of events; benefits furthermore, when the picturesque and vacationer undertakings to build the travel industry in the between area vertical and level mix of the chain, the entire business bind in the capacity to meet the different necessities of vacationers will keep on improving; At last, the consolidation conduct of the travel industry endeavors and traveler data effectively discharge likewise emphatically affect the whole chain of between local the travel industry .

\section{REFERENCES}

1. Saget C (1999). The determinants of female labour supply in Hungary. Economics of Transition 7(3): 575-591. 
Published: November 30, 2021 | Pages: 35-39

2. Wooldridge $\mathrm{J}$ (2002). Econometric analysis of cross section and panel data. Cambridge: The MIT Press.

3. Wang Yingluo. Systems Engineering [M]. Machinery Industry Press, 2003 : 64-73.

4. Vladimir Grujić, V. V. (2012). Crisis management of small and medium enterprises . International Scinetific Conference "Management 2012".

5. Schumpeter, J. A. (1934). The Theory of Economic Development. Cambridge, Mass: Harvard University Press.

6. Yahya, M. 2003. The antecedents of customer-contact employees' empowerment. Employee Relations, Emerald Group Publishing Limited. 26(1):72-93. 


\title{
EPIGRAPHIC MONUMENTS AS A HISTORICAL SOURCE ON THE HISTORY AND CULTURE OF THE KARSHI OASIS
}

\author{
Shukhrat Shonazarov \\ National University of Uzbekistan
}

\begin{abstract}
Epigraphic monuments are an important historical source for the study of the history of Central Asia. In recent years, continuous archaeological and epigraphic surveys of the Karshi oasis have been undertaken. A significant number of epigraphic monuments gravestones - have survived to this day. The value of such monuments is that they have preserved for us information on many issues of ethnic terminology, toponymic nomenclature, ethnic migrations in the past, the activities of builders, the role of the rural community. Particularly important are information about feudal rulers, their activities, social terminology, data on the specific history of the peoples of the Karshi oasis and Central Asia as a whole.
\end{abstract}

KEYWORDS: Epigraphy, stone master, calligrapher, arts, archeology, toponymy, Karshi oasis, tombstones, Central Asia, Sufism, Ishkiyya and Naqshbandiyya.

INTRODUCTION: Epigraphic monuments are an important historical source for the study of the history of Central Asia. The inscriptions, carved on hard materials or made on ceramics, as well as carved on wood, retain their former appearance for a long time and transmit the facts contained in them to future generations. Epigraphic monuments are the product of medieval stone-cutters and calligraphers, reflecting the inner and spiritual world of educated and cultural personalities of their era.

In recent years, the Department of Archeology of the National University of Uzbekistan has undertaken continuous archaeological and epigraphic surveys, and work is underway to compile an archaeological map and database based on the GIS (Geographic Information Systems) technology of the Karshi oasis.

A significant number of epigraphic monuments - gravestones - have survived to this day. For example, gravestones with inscriptions have been preserved mainly in old cemeteries, at sites associated with the cult of saints. Gravestones are usually placed in the open air, the 


\section{PEDAGOGY AND MODERN EDUCATION: TRADITION, EXPERIENCE AND INNOVATION}

Published: November 30, 2021 | Pages: 40-43

surface of many of them has been destroyed by the influence of natural factors, as a result of which some of the inscriptions are unreadable or partially traced.

THE MAIN FINDINGS AND RESULTS.The expansion of cotton fields in the era of the socialist system and the development of the irrigation system associated with agricultural technology led to the deterioration of the soil in the zones where the monuments of architecture and gravestones are located. It should be especially noted that the rise of subsoil waters and salts leads to the destruction of cultural monuments. It should be borne in mind that many gravestones were destroyed, or disappeared and were not found. Here you can add the process of restoration and repair work, as a result of which the appearance of many architectural structures remains altered.

The gravestones of the Karshi oasis contain many, often very important, information about the economic, political, cultural and daily history of the peoples of Uzbekistan for several hundred years. The value of such monuments is that they have preserved us information on many issues of ethnic terminology, toponymic nomenclature, ethnic migrations in the past, the activities of builders, the role of the rural community. Particularly important are information about feudal rulers, their activities, social terminology, data on the specific history of the peoples of the Karshi oasis and Central Asia as a whole.

With the help of epigraphic data, you can get new information about the history of this little-studied region, especially in the genealogy and anthro-understanding of local religious figures (sheikhs, ishans), hereditary sayyids and khodjas (descendants of the Prophet Muhammad through his daughter Fatima and four righteous caliphs). Many tombstones at one time were installed in the memory of representatives of the state-administrative system and until now the names, epithets, nisbs of such persons are absent in other historical sources.

Thus, the inscriptions, as it were, supplement the history with new information and expand the field of source research. Studying them, we have the opportunity to obtain new information about the objects of Sufism, after the death of representatives of such orders, their burial places turned into objects of worship (ziyaratgahi), which are still frequently visited today.

Among such visiting centers, one can list the memorial and burial complexes of Abu Ubayd ibn Zharrah, Kurganch mosque-khanaka (Karshi city), Sultan Mir-Khaidar, Hezreti Khusam-ata 


\section{PEDAGOGY AND MODERN EDUCATION: TRADITION, EXPERIENCE AND INNOVATION}

Published: November 30, 2021 | Pages: 40-43

(Kasbinsky district), Imam Main, Hezreti Sheikh Shamsutdin Ata (Karshni ), etc. Together with these on the territory of the region there are dozens of objects of the cult of saints. In all these places there are gravestones testifying to the representatives of the Sufi eagles, such as Ishkiyya and Naqshbandiyya.

The results of studying the inscriptions on the gravestones provide new information about historical figures, especially about the genealogy and chronology of unknown religious figures and secular persons. Accurate information can also solve issues related to the cults of saints, whose history is still legendary.

The epitaphs on the gravestones, in comparison with other historical sources, make it possible to reconstruct the genealogy and make it possible to form new ideas about kinship and genealogy of certain social groups. In this regard, special attention is paid to the hereditary relations of religious groups of Sayyids, Khojas, Sheikhs, as well as emirs and other officials of a secular nature.

These kinship relations have not lost their significance in individual settlements, where strict adherence to kinship ties still exists. Representatives of such social strata are based on the "Shajar" of their ancestors to prove their innocence. They still keep written evidence at home with great care and refer to the data on the gravestones, where the names of their ancestors are present, in extreme cases, to the khanaka, macbarat or sagan, associated with the names of their authoritative ancestors.

Of great importance are the symbolic signs carved on the gravestones, for the study of which, in addition to historical research, art history analysis is also required. Here we must add the types and forms of gravestones, different in appearance and characteristic of each century. Research results in recent years show that, starting from the era of Amir Temur and temurids, well-worked, chest-like gravestones in the form of steles, and later elongated stones (tombstones of a trapezoidal section) are already encountered ${ }^{1}$. But the richest in decoration and ornamentation are the gravestones of the era of Amir Temur and temurids and, in part, Sheibanids.

On the gravestones there are often poetic texts - marsias (elegies), original in their kind and little-studied from the point of view of history and philology. In addition to the marsias

\footnotetext{
${ }^{1}$ Шоназаров Ш.Б. Классификация намогильных камней XV-XIX вв. (по материалам Каршинского оазиса) / Ўзбекистон тарихи. 2003. №1. С. 11-15.
} 


\section{PEDAGOGY AND MODERN EDUCATION: TRADITION, EXPERIENCE AND INNOVATION}

Published: November 30, 2021 | Pages: 40-43

extracted from the poetic works of Saadi and Hafiz, specially composed days of important persons of that era can be noted.

Textual studies and paleographic analysis makes it possible to judge the literacy of the population, the calligraphic features of the medieval schools of calligraphy, the process and order of writing a text.

Inscriptions are the transmitter of the art of stone cutters and calligraphers. Based on them, we can identify the types and types of writing characteristic of different eras and for individual territories, note the impact and impact of one or another school of calligraphy. The study of grave inscriptions requires a comparative analysis with other types of writing, and most importantly, paleographic analysis.

Thus, a lot of facts can be cited about the significance of the epigraphic monuments of Muslim culture. Until now, only a small number of them have been used as a historical source. But, unfortunately, in recent years, their number began to decline sharply under the influence of climatic and environmental factors.

CONCLUSION. A large amount of epigraphic material has been accumulated, for the study of which the skills of a scientific approach are required, which will make it possible to turn to systems-analytical research based on modern methods, that is create a database, thanks to which a fund of information is created to identify interregional and long-distance ties between specialists.

Thus, the accumulated significant material and experience in the study of epigraphic monuments of the Karshi oasis find worthy application in archaeological, historical, linguistic, artistic, toponymic and other sciences.

\section{REFERENCES}

1. Шоназаров Ш.Б. Классификация намогильных камней XV-XIX вв. (по материалам Каршинского оазиса)/Ўзбекистон тарихи. 2003. №1. С. 11-15.

Shonazarov Sh.B. Classification of gravestones of the 15th-19th centuries (based on the materials of the Karshi oasis)/ Y̌zbekiston tarikhi. 2003. No. 1. S. 11-15. 


\title{
THE EFFECT OF COACHING, THE BOARD BACKING AND PREPARING AND ADVANCEMENT ON THE REPRESENTATIVES' WORK EXECUTION
}

\author{
Hasni Meon \\ Department of Economics, KDU University College, Malaysia
}

ABSTRACT: This review investigates the work execution by inspecting the relationship on coaching, the board backing and preparing and improvement in State Government Advancement Office of Sabah. Issues, for example, the intricacy of the staffs from the diverse segment and change of ICT frameworks give added bits of knowledge to this review. The procedure for this review is utilizing quantitative methodology. The discoveries of this review uncover that tutoring, the executives backing and preparing and improvement have critical positive relationship with work execution. This review suggests that human asset the executives in all over Sabah Improvement Office in Malaysia should carry out such practices to forming and executing techniques of representatives' work execution at the work environment.

KEYWORDS: Occupation Execution, Coaching, The board Backing, Preparing and Improvement.

INTRODUCTION: Malaysia Super Passage is Malaysia's drive for the worldwide data and correspondence innovation industry. Issues, for example, the intricacy of the staffs from the distinctive segment and change of ICT frameworks has turned into the dangers of for public area with respect to of the work execution among their staff. Because of this explanation, see how the human asset advancement framework in explicit tutoring, preparing and improvement also as overseeing backing can impacted the representative's work execution. The point of this review is to investigate the work execution by inspecting the relationship on tutoring, the board backing and preparing and advancement in State Government Improvement Office of Sabah. Issues, for example, the intricacy of the staffs from the diverse segment and change of ICT frameworks give endeavored to fill the hole by exploring to comprehend and inspect the coaching, preparing and advancement and the board support in what the method for significance for the representative's work execution. 


\section{PEDAGOGY AND MODERN EDUCATION: TRADITION, EXPERIENCE AND INNOVATION}

Published: November 30, 2021 | Pages: 44-48

Then again, as indicated by Poulsen there is an alternate meaning of coaching among USA and UK where in USA tutoring model expects that the guide have more status and power than the mentee yet UK model is that the tutor has important experience which is significant to the mentee and that the mentee assumes liability for his/her own learning. Other than that, tutoring is characterized as a steady connection between youth or youthful or protégé and somebody who will offer help, direction and substantial help as the more youthful accomplice goes through a troublesome period, takes on significant assignments or remedies and prior issues. Also, tutoring is an endeavor to move insight and mastery for a fact people in an association to the less experience and can be utilized as a sort of quick track support plot where one ranking director manages the action and execution of a lesser partner who is reserve for fast movement. With the end goal of this review, Tutoring alludes to an individual formative relationship where a more experienced or more proficient individual aides a less experienced or less learned individual. Then, the executives support hands on execution which is strengthening and trust was examined. As per Ivancevich and strengthening characterized as empowering and/or helping individual and gatherings to settle on choice that influence their workplace. Other than that, as indicated by Lashley, representative strengthening has been hailed as an administration strategy which can be applied all around across all associations as a method for managing the requirements of current worldwide business and across every modern area. Yahya tracked down that, strengthening characterized is worried about giving workers greater power and caution in the undertaking and setting related issues. With the end goal of this review, strengthening viewed as power which to be practiced in three aspects which by utilizing different assets to impact the result of dynamic cycles, in the subsequent aspect, by controlling admittance to those cycles, and, in the third aspect, through domineering cycles, which implies the legitimization of force through social and standardizing suspicions. Trust can be characterized as conviction that those on whom we depend will meet our assumption for them. There is motivating confidence in the pioneer and what the one individual is attempting to accomplish and that pioneer trusting on the subordinate all together the achieve what they needs. Other than that, as indicated by Joseph and Winston observed that there are a few extra factors are related with a culture of confidence in an association, including the profundity and nature of relational connections, clearness of jobs and obligations, recurrence, practicality, and straightforwardness of correspondence, skill to take care of 


\section{PEDAGOGY AND MODERN EDUCATION: TRADITION, EXPERIENCE AND INNOVATION}

Published: November 30, 2021 | Pages: 44-48

business, lucidity of common perspective, course and vision and regarding guarantees and responsibilities. With the end goal of this review, trust is viewed as how much trust exists can decide quite a bit of an association's person, affecting elements like hierarchical construction, control.

TECHNIQUE. Money, Destitution Destruction, Exceptional, Specialized, Observing and Assessment just as IT Area, from driver until the upper administration in Sabah Government Improvement Office. It was formed into three areas which is segment, coaching segment, preparing and advancement segment, the executives support segment and finally is work execution segment. All things with the exception of segment area were estimated utilizing a Likert-type reaction scale going from firmly differ to emphatically concur.

Conversation In this segment, the conversation was covering the connection between tutoring, the board backing and preparing advancement with work execution. The aftereffects of this review uncover that tutoring influences the workers' work execution. In other word, there is a huge connection among coaching and occupation execution. This review is steady with past researchers that coaching is an endeavor to move insight and skill as a matter of fact people in an association to the less experience and can be utilized as a sort of quick track support plot where one ranking director supervises the action and execution of a lesser partner who is reserve for fast movement. The coaching can be utilized to work on the representatives' exhibition. The representatives who get the coaching are more successful in taking care of their business than for those didn't get the tutoring, tutoring as a compelling method for upgrading work results and profession advancement. Thusly, in this review, it was obvious to show that workers' work execution were profoundly increment when there is an upgrade on coaching towards the representatives.

Then again, the aftereffects of this concentrate likewise uncover that administration support (trust and strengthening influences the workers' work execution. In other word, there is a critical connection between the executives backing and occupation execution. This review is reliable with Martin and Ledford and when they uncovered the doubt by the worker will be existed and will be impacted their exhibition. It is additionally understanding with Green and Macandrew, the strengthening given by the top administration can be added to the representatives' efficiency (execution). Finally, the consequences of this concentrate 


\section{PEDAGOGY AND MODERN EDUCATION: TRADITION, EXPERIENCE AND INNOVATION}

Published: November 30, 2021 | Pages: 44-48

additionally uncover that preparation and advancement influences the workers' work execution. In other word, there is a critical connection among preparing and advancement and occupation execution. These discoveries support the investigations by past study done by Gunasegaran, preparing and advancement is arranged, persistent exertion by the board to further develop representative ability level and hierarchical execution. Hence, in the field of human asset the board, preparing and improvement is the field worried about authoritative action pointed toward bettering the presentation of people and gatherings in hierarchical settings.

SUGGESTIONS. This review uncovered that coaching, the executives backing and preparing advancement are essentially identified with the representatives' work execution. The discoveries for this review can be utilized in Execution and Coordination Unit (ICU), Top state leader Office as a rule and benchmark to further develop their all branches altogether in Malaysia. Then again, the discoveries are extremely educational in clarifying and tackling a few issues relating of human asset parts of association towards the workers' work execution among the representatives in SDO Sabah. The review has given a top to bottom comprehension on the connection between coaching, the board backing and preparing advancement with work execution of the representatives. From the outcome acquired, this review propose that the administration in SDO ought to consider a few factors that have been recognized to be the indicators of occupation execution and can be join them in any representatives' advancement program to work on workers' presentation in the working environment. Ultimately, thought on the variables, indicators and impact of occupation execution might help in decrease of human asset issues among workers in the association particularly in regards to the tutoring, the executives backing and preparing and advancement issues. The discoveries of this review will be extraordinary assistance to give a comprehension to the board of SDO in planning arrangements and systems for what's to come.

\section{REFERENCES}

1. Yahya, M. 2003. The antecedents of customer-contact employees' empowerment. Employee Relations, Emerald Group Publishing Limited. 26(1):72-93.

2. Thomas F. Addressing the Measurement of Tourism in Terms of Poverty Reduction: Tourism Value Chain Analysis in Lao PDR and Mali[J]. International Journal of Tourism Research, 2013. 


\section{PEDAGOGY AND MODERN EDUCATION: TRADITION, EXPERIENCE AND INNOVATION}

Published: November 30, 2021 | Pages: 44-48

3. Van Ham M, Büchel F (2004). Females" willingness to work and the discouragement effect of a poor local childcare provision. IZA 1220.

4. What is General Aviation. (2012, November 17). Retrieved from AOPA: http://www.aopa.org/

5. Schumpeter, J. (1911). The Theory of Economic Development: An Inquiry into Profits, Capital, Credit, Interest and Business Cycle, Cambridge Mass: Harvard University Press. 


\title{
THE ROLE OF LARGE MARKETS IN THE LIFE OF THE COUNTRY DURING THE REIGN OF AMIR TEMUR AND THE TEMURIDS
}

\author{
Alisher Egamberdiyev \\ 1st year Master Student, Faculty of History, National University of Uzbekistan named after \\ Mirzo Ulugbek, Uzbekistan \\ Ozodbek Nematov \\ 1st year Master Student, Faculty of History National University of Uzbekistan named after \\ Mirzo Ulugbek, Uzbekistan
}

\begin{abstract}
In a place where trade is developed, handicrafts have long been made based on its needs, markets have flourished and the living standards of the country's population have increased. Therefore, Timur and his successors attached great importance to the development of trade, which played an important role in the economic life of the country.
\end{abstract}

KEYWORDS: Ahanin, Feruza, Sozangaron, markets, Clavijo.

INTRODUCTION: In the central cities of Transoxiana and Khorasan, the number of closed markets - chorsu - increased, and the rastas expanded. When it comes to the time of Amir Temur, domestic and foreign market relations in the country were fully supported by Temur himself. During his reign, a great deal of work was done to improve trade routes and markets, roads, and caravanserais on major caravan routes. During this period, markets became not only a place where economic relations collided, but also a place where other important issues of the country's social life took place. In short, the market was the center of city life. It has also served as a forum for exchanging views on achievements in various fields. Here the orders of the ruler were read out and the guilty were punished.

THE MAIN FINDINGS AND RESULTS. The development of trade and handicrafts in Samarkand, the capital of the country, during this period surprised the Spanish ambassador Rui Gonzalez de Clavijo, who visited Samarkand from the Mediterranean in 1402-1404 via Iraq-Iran-Khorasan. Klavikho, who was in Timur's reign in 1404, wrote in his memoirs that due to the lack of a convenient trading post in Samarkand, Amir Temur ordered the construction of a main street 


\section{PEDAGOGY AND MODERN EDUCATION: TRADITION, EXPERIENCE AND INNOVATION}

\section{Published: November 30, 2021 | Pages: 49-52}

across the city and the construction of rastas and shops on both sides. . The street, which was built on the orders of the owner, was to start at the outskirts of the city, run through the whole city and connected to the other end. On the instructions of Amir Temur, the street will be built in the direction determined by him. In the process, the houses on the street will be demolished and leveled, regardless of who owns them.

Clavijo puts it this way: "The street was widened, and shops were built on both sides of it, and high benches covered with white stones were erected in front of each shop. All the shops are connected in pairs. The top of the street is arched from head to toe. It has a series of windows to let in the light. As soon as the shops were built, merchants settled in them and began to sell various goods. Pools were dug all over the street, and they were filled with water ... People who worked during the day would go home late, and others would come to work at night instead, some would demolish the houses, others were flat on the ground and still others were busy with construction... The fact that such a large construction was completed in less than twenty days is certainly astonishing"[1].

In Samarkand, the gates of Ahanin, Feruza, Sozangaron, Gozuristan (Korizgoh), Bukhara and Shaykhzoda (Chorraha) marked the roads from six sides of the city. Starting at the gates, the city streets connected to the central market. Specialized market stalls traded with a specific type of product. This feature of the Samarkand markets was admired not only by the historians of that period, but also by the authors of the next period. In his memoirs, Zahiriddin Muhammad Babur shows that during the reign of Amir Temur there were trade stalls specializing in Samarkand goods. [2]. Usually, the name of the rasta was determined by the name of the product it was sold on. The markets were crowded with city trades, including handicrafts. Many of the shops were not only places of trade, but also places where artisans made and sold their products. Most of the artisans lived in the squares of the city markets. Amir Temur paid special attention to equipping the markets of the city.

In the central market of the city there is an exchange office. The market was also a place where prices were set for products. Vendors were severely punished and traders were protected when prices were too high. In the country's markets, there was even a separate post that controlled the accuracy or curvature of prices and scales. Such officials are called muhtasibs, who are responsible for overseeing public order and preventing corruption. As noted above, they prevented the hitting of stones and scales in the markets and other offenses 


\section{PEDAGOGY AND MODERN EDUCATION: TRADITION, EXPERIENCE AND INNOVATION}

Published: November 30, 2021 | Pages: 49-52

that may have taken place there, maintained order, and carried out punitive measures in accordance with their duties.

During this period, markets became not only a place of trade, but also a center of awareness of the processes taking place in the country. It was also used for socio-political purposes due to its crowded markets and crowded places. In particular, during the reign of Amir Temur, punishments for criminals were carried out not in secret from the people, but openly in markets and open areas. It served as an educational tool for the coercive apparatus. Those who witnessed the process were convinced through live punishment that the best way to avoid crime in the country, no matter how big or small was not to steal in the markets, not to deceive customers, and to engage in honest trade.

The bazaars were usually filled with spectators, magicians, wrestlers, and puppets. The dor game was especially popular and no holiday was complete without it. Both the nobility and the people believed in darboz as an example of courage and purity. Dor gathered thousands of people in large squares and markets, inspiring the audience with courage, generosity and kindness. During the month of Ramadan, the bazaar's night rituals (bazaar-i-shab) were attended by palace music groups, the mehtar, which were personally appointed by the ruler and consisted mainly of trumpeters and drummers.

The tradition of receiving foreign ambassadors with respect has been preserved in the reign of his descendants since Amir Temur. The ambassadors' perceptions of the country's power also depended on its markets. After all, a country with abundant markets will be more economically powerful. In this regard, the historian Abdurazzaq Samarkand writes about the meeting of the Chinese ambassadors in Herat in 1413, in particular: (By Haqqani Sa'id Shahrukh) A humorous decree was issued: "Let the city markets be adorned, and let every artist show his craft and decorate his shop." [6] It is clear from this record that Shokhrukh wanted to show the ambassadors not only that the markets were full, but that the handicrafts sold there were not inferior to those of other countries, but had risen to the level of art.

CONCLUSION. In short, during the reign of Amir Temur and the Temurids, markets became the centers of social processes. It was used not only as a place for trade, but also as a bridge for communication between the people and the state due to the crowds in the major markets: decrees and important political messages were read in the markets. The functioning of the markets was controlled by private officials. Depending on the markets, the economic situation 
of the country, the living standards of the population, and the presence of foreign traders in it, it was possible to assess the creation of a safe and peaceful environment in the country. The bazaars were even used as a place for handicrafts to be exhibited by dignitaries and ambassadors from abroad.

\section{REFERENCES}

1. Saidqosimov S., Ahmedov A., Ahmedov B. et al. Amir Temur in world history. Completed and revised second edition. Tashkent: Sharq, 2001. - p. 95.

2. Zahiriddin Muhammad Bobur. Boburnoma. Tashkent: 1993. - p. 106.

3. Sharafuddin Ali Yazdiy. Zafarnoma. Preparation for publication, introduction, comments and indicators by A.Urinbaev, Tashkent: 1972. - p. 124.

4. Oljaeva Sh. The development of national statehood during the reign of Amir Temur and the Temurids, Tashkent: Fan, 2005. - p. 164.

5. G'ofurbekov T. Music // Culture and art in the time of Amir Temur and Temurids. Articles. Tashkent: G. Gulom Literature and Art Publishing House, 1996. - p. 41 .; Saidqosimov S., Axmedov A., Axmedov B. et al. Amir Temur in world history. Completed and revised second edition. Tashkent: Sharq, 2001. - p. 182.

6. Abdurazzoq Samarkandiy. Matlai sadayn and majmai bahrain. Translated by A. Urinbaev. Responsible editors Azimjanova and U.I. Karimov. Tashkent: 1969. - p. 174-175. 


\section{ADVANCED PHONE HELPED LANGUAGE LEARNING}

\section{Ali Husain Abbas \\ Komar University of Science and Technology, Iraq}

ABSTRACT: These days cell phones surprisingly affect language learning. Since it isn't possible to live without cell phone and each and every individual has no less than one. Most students consider cell phone applications as a huge office in the advancement of language learning. Versatile learning at the end of the day m-learning is an extremely new point. This term likewise covers with e-discovering that implies learning by electronic gadgets like PCs, PCs, tablets and web. M-learning can happen either in-homeroom or out-of-study hall. Projects or applications can be downloaded and introduced without any problem.

KEYWORDS: Cell phone Helped Language Learning, Versatile Learning, E-learning.

INTRODUCTION: Today English is the main second language from one side of the planet to the other. That is the reason creating supportive cell phone applications for empowering compelling English learning is an imperative issue in the English language concentrating on region (Collins, 2005). Understudies need to remember and rehearse an enormous number of jargon and they ought to learn syntactic constructions to have adequate English.

Advantages of Advanced cell Helped Language Learning

There are a great deal of benefits of cell phone helped language learning. Some of them are; Shopping center permits understudies to get to language learning materials effectively and all the more rapidly and speaks with others whenever and anyplace. The personality of advanced innovation ease students" partake in both group and individualized language learning exercises permitting quick improvement of talking, perusing, tuning in, and composing, abilities. Portable innovation supplies a few assets and gadgets for language discovering that move students to be more propelled, sure, and social.

The best application doesn't attempt to do everything. It intends to foster one thing especially. Application creators who come from the work area registering regularly over- 


\section{PEDAGOGY AND MODERN EDUCATION: TRADITION, EXPERIENCE AND INNOVATION}

\section{Published: November 30, 2021 | Pages: 53-55}

burden a lot into a program. Cell phone clients don't need one application perform everything and they need bunches of little projects that foster one thing admirably. So as educators we ought to characterize first on what reason we really want the application for.

Instructors can get ready jargon practices canvassed in the homeroom. Understudies can be given the task in the study hall and requested to achieve them through their cell phones prior to sending them back to the educator. SMS is one more typical strategy for learning new jargon dependent regarding the matters canvassed in the homeroom. Vocabularies can likewise be clarified by the photos displayed on learners" versatile showcases for better cognizance of new words.

Perusing entries assist students with improving their jargon information and assist them with advancing understanding perception. Perusing exercises can be passed on to students through email or SMS. After that they may requested to answer the task to assess. Innovation changes step by step and another gadget come into life consistently. Likewise digital books might permit more friendly environment, with a gathering of understudies collaborating to peruse, talk about on a similar point, every one of them are utilizing their own gadgets.

Games and game-like exercises are for all sort of individuals who like them. Such games can be incorporated to language learning exercises without any problem. Particularly language and jargon games are habit-forming for grown-ups. At the point when they attempt to expand their high scores they get familiar with a great deal of syntax rules and new words. Games may look like for kids, yet remember on the cell phone, grown-ups likewise like messing around, too. Hence, even the projects that are not actually games might contain game-like highlights. As in the games they have input cycles, grants, get additional properties. The trouble of attempting to finish areas or to arrive at better scores will hold understudies playing and learning. Then again paper based exercises would immediately become dreary.

CONCLUSION. Understanding the reasonableness of versatile learning will require new jobs for instructors. One snag to the improvement of versatile learning is the absence of experienced teachers who can productively adjust portable innovations into their examples. There is immense interest in research on the techniques that helps giving advantageous Shopping 
center climate to students. Likewise, a few abilities as tuning in and talking need further upgrades in Shopping center exploration.

Advancement in innovation causes different sorts of portable innovation, like tablets and PCs with many additional capacities. Cell phones currently have similar elements as microcomputers. Cell phones improve the learners" independence and coordinated effort. In other word, Shopping center can be a viable recipe to language learning hindrances as far as spot and time. Cell phones can't substitute qualified instructors, yet the developing pattern of cell phones among ESL students fabricate conceivable outcomes to give extra language practice whenever, anyplace.

\section{REFERENCES}

1. Miangah, T., \& Nearat, A. (2012). Mobile-assisted language learning. International Journal of Distributed and Parallel Systems, 3 (1), 309-319.

2. Lane, J. (2006). NTP, Inc. v. Research in Motion, Ltd.: Inventions Are Global, But Politics Are Still Local-An Examination of the BlackBerry Case. Berkeley Tech. LJ, 21, 59.

3. Ambros T. s.a. Surse regenerabile de energie. Manual, Chisinau: Editura «Tehnica-info», 1999.

4. Sternad, M. (2012). Socialnopedagoško sodelovanje z družinami z več problemi [Sociopedagogical collaboration with families facing multiple problems]. Socialna pedagogika, $16,437-468$.

5. Rondinelli, D. A. (1981). Government Decentralization in Comparative perspective: International

6. Review of administrative sciences 2 . 


\section{EVOLUTIONARY APPROACHES OF THE SOCIAL SERVICES SYSTEM TO THE NECESSARY STAGES OF THE POPULATION}

Bekzod Tolibov

\section{Basic PhD Candidate, Fergana State University, Uzbekistan}

ABSTRACT: The article examines the historical forms and manifestations and the evolutionary memory of the system of social services for those in need. The issue of social protection of the needy, the organization of assistance in the form of social services in their difficult life situations has always been relevant. The main factors influencing the formation of the specifics of this process are the balance between the productive forces at the stages of development of society, the organization of labor and employment, social, economic, political, spiritual and cultural ideas, traditions, the way of life of different people. nations and peoples in society. The process of providing social services to those in need can be understood as the theoretical foundations and stages of the formation and development of the practice of this system, the same issues are investigated in detail in this article.

KEYWORDS: Social service, needy, social protection, social work, community, charity, technology, method.

INTRODUCTION: The end of the IV millennium In the beginning of the III millennium in the territory of the ancient East - between the Frot and the Tigris, between Babylon, the Amu Darya and the Syr Darya, the Sogdian, Bactrian and Merv states, the first states in ancient times, such as Egypt on the banks of the Nile. Initially, they were small city-states, but later some of them became powerful empires. Later, similar cases can be observed in China, India, and Asia Minor. It is known from historical sources that in these ancient countries certain categories of the needy were also provided with certain assistance. Some of them are dedicated to helping the needy by the state or the public, while others have been preserved in various religious teachings on the moral ideas of helping the needy.

The provision of social services to the needy first appeared thousands of years ago in Buddhism, Monism, Mazahism, Zoroastrianism, and in Islam as a religious duty of philanthropy. By the twentieth century, it had become a specialized profession in the form of social work or 


\section{PEDAGOGY AND MODERN EDUCATION: TRADITION, EXPERIENCE AND INNOVATION}

\section{Published: November 30, 2021 | Pages: 56-59}

social service that required special training. It is necessary to scientifically and theoretically substantiate the difference between those who are engaged in religious charity and the modern social worker, noting the deep humanitarian sources of social work.

Social services, which do not appear as a duty of religious enlightenment, have always empowered philanthropists to strive to do humanitarian work, which is measured by the amount and duration of assistance provided to people. According to sociologist T. Shanin, a modern social worker, his task is to bring the person he is helping to a level where he can overcome difficulties without such help and without the intervention of a social worker, which is the main criterion for success in the profession of social worker. [1]

THE MAIN FINDINGS AND RESULTS. Social work as a social phenomenon represents a specific model of social assistance in the broadest sense. This is done in a specific historical period, depending on the characteristics of the social, political and cultural development of the society. In the narrow sense, social work is a socially necessary activity aimed at helping people, social groups, overcome personal and social difficulties. "Social work" is a universally accepted expression of human positive attitude towards human beings and activities aimed at facilitating human adaptation to society. [2]

Based on the needs of society, it can be noted that there are grounds for the formation of the field of social work as a separate science and a separate specialty in the system of social sciences and humanities as a professional specialty.

It can be said that there are a number of historical reasons why social services have emerged as a separate area of existing activity in society. As a social phenomenon in society, the first manifestations of social assistance, expressed in the care of people in difficult life situations due to social work illness, disability, freedom, social status, depend on the specific features of traditions and values formed in societies.

In ancient Egyptian temples, priests distributed bread free to the hungry. In ancient Greece, and then in Ancient Rome, the idea of philanthropy developed, which was reflected in the distribution of bread, clothing, money among the poor. In the ancient Slavs, on the other hand, religious support with various traditional symbols, social kinship within the tribe, family, population, as well as economic assistance, mutual assistance and protection were the main forms of social protection. In the ancient East, on the other hand, from the middle of the third 


\section{PEDAGOGY AND MODERN EDUCATION: TRADITION, EXPERIENCE AND INNOVATION}

\section{Published: November 30, 2021 | Pages: 56-59}

millennium BC, giving alms to the needy was considered a very religious duty and was considered obligatory for believers. [3]

A similar situation can be observed in Ancient Mesopotamia, located between two rivers, and in a number of city-states of Sumer. As a result of the somewhat accelerated implementation of state-building in this region, a strong centralized ancient kingdom was formed in a short period of time. According to historians, the city of Lagash, one of the cities of Sumer, was reformed in the social sphere by the ruler Urukagin around 2370 BC, as a result of which the common people were less oppressed by the state and the aristocracy.The following words can be found in one of the surviving inscriptions in the ancient Sumerian inscriptions. "With the help of God, Ningirsu Urukagin established this order so that orphans and widows do not surrender to a strong land" and a number of decrees were issued to protect and support orphans, widows, people with disabilities and the poor. [4]

In 1200 BC, methods of social assistance also existed in Ancient Israel (Judea). Many of the provisions of the Covenant that came from God to the Prophet Moses (peace be upon him) were applied directly or indirectly. It is known that the foundation of Judaism is the Holy Torah, which contains the ten commandments that Moses received from the Lord on Mount Sinai. [5]

With the spread of Christianity in the Western and Eastern Roman Empire, a number of normative and legal documents on social issues were adopted. In particular, in 347, the Sarduki Main Church adopted twelve regulations on aid to the poor, orphans, widows, and strangers. At the same time, the system of shelter and food, which is reflected in the distribution of donations and food for the poor, has a priority. [6]

In our opinion, the increase in social problems in society has also led to the problem of poverty, which is confirmed by the world community as a factor that negatively affects the stability and order of the state and society. This situation has led not only to the emergence of legislation in the world that regulates relations in the field of social services, but also to the study of the needy strata of the population through sociological research.

The use of modern methods and technologies that allow to provide effective social services to the needy and improve the system of social services in Uzbekistan are the priorities of social policy in Uzbekistan. Effective social services can be achieved in Uzbekistan through the establishment and development of a regional network of social services, training of qualified specialists in the field of social work, social pedagogy and applied psychology. 


\section{PEDAGOGY AND MODERN EDUCATION: TRADITION, EXPERIENCE AND INNOVATION}

Published: November 30, 2021 | Pages: 56-59

CONCLUSION. Also, in the "Action Strategy for the five priority areas of development of the Republic of Uzbekistan in 2017-2021" to increase the activity of social protection, including the system of medical and social assistance to pensioners, the disabled, lonely elderly and other needy people Further development and improvement "sets specific tasks on this issue. [7] This, in turn, indicates that the issue of improving the efficiency of social services to the needy is one of the most important areas of public policy in the social sphere.

\section{REFERENCES}

1. Shanin Theodore. Social work as a cultural phenomenon of modernity. New profession and academic discipline in the context of social theory and political practice of our world // Russian Journal.№4. September 26, 1997 - S.74-78.

2. Ganieva M.X. Fundamentals of social work. Methodical use - Tashkent, 2010. - B.5-6.

3. Spirina V.I., Spirina M.L. History of social work: uchebno-metodicheskoe posobie // Nauchnby red. d.p.n., prof. Spirina V.I .; otv. ed. k.p.n., dots. Spirina M.L. - Armavir, 2019 $-\mathrm{S} .26$.

4. Men A. History religii v 7-mi t. - T 2. - M., 1991. - S.87.

5. Фирсов М.В. Антология социальной работы в 5 т. - Т.1./ - М.,1994. - С.490.

6. Kuzmin K.V., Sutyrin B.A. History of social work for the ruble and in Russia (from antiquity to the beginning of the $\mathrm{XX}$ century). - $\mathrm{M} .:$ Akademicheskiy proekt; Ekaterinburg: Delovaya kniga, 2002. - S.11.

7. Decree of the President of the Republic of Uzbekistan dated February 7, 2017 No PF4947 "On the Action Strategy for further development of the Republic of Uzbekistan" // www.lex.uz 


\title{
DETERMINED CRITERIA FOR DIVERSIFICATION IN INDUSTRIAL ENTERPRISES
}

\author{
Davronbek Raximov \\ PhD student, Fergana State University, Uzbekistan
}

ABSTRACT: The article examines the established criteria for industrial diversification, highlights various forms of diversification of companies, develops scientific proposals and practical recommendations for the development of processes of diversification of industrial production.

KEYWORDS: industry, diversification, criteria, enterprise liquidity, production, quantification, synergistic efficiency, company.

INTRODUCTION: The main reason for diversification is the process of globalization of production, which is associated with the effect of saving from the scale of production, ie synergistic effect.

The following reasons for diversification of production are identified:

- reducing the level of risk, which allows you to stabilize the financial situation for a certain period of time;

- $\quad$ as the best way to invest capital;

- business expansion due to synergistic effect.

Incentives to diversify production are shown in Figure 1.

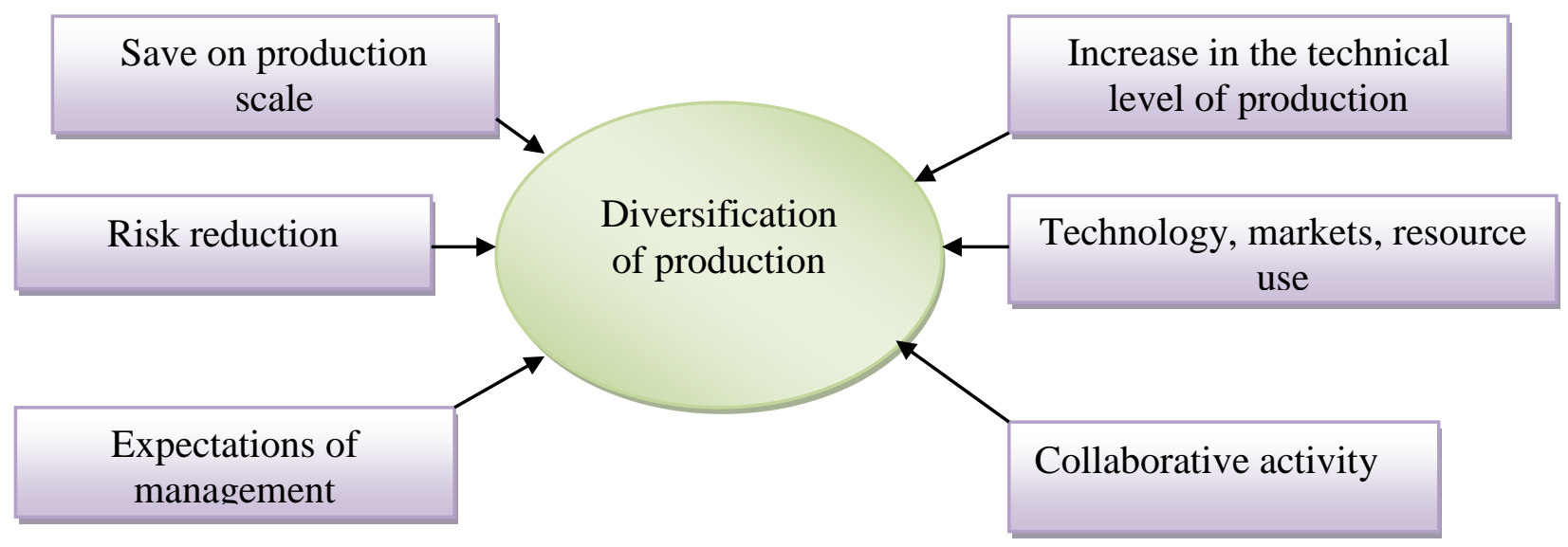

Figure 1. Incentives to diversify companies 


\section{PEDAGOGY AND MODERN EDUCATION: TRADITION, EXPERIENCE AND INNOVATION}

\section{Published: November 30, 2021 | Pages: 60-64}

- the exchange is specific to the existing "product-market" combination and has lost its vitality due to "spiritual" obsolescence or stiff competition;

- Applying the supplement to the existing "product-market" combination, the increase in capacity will reach the stage of maturity, if it does not justify the use of permissible resources and tools;

- insurance - to compensate for conditions or a decline or possible oversupply of the market. This is done by investing and distributing risk to all sectors of production.

These diversification incentives are able to apply separately and, depending on the specific situation, their different combinations with each other take place. Therefore, the choice of one or another type of diversification by the company should be well-founded and carefully planned.

According to Aronov, the driving force behind the diversification of enterprises are the following factors: the goals of the company's management, the dynamics of the business environment and the resource potential of the enterprise. They define the criteria for diversification of the enterprise:

- attractiveness criteria;

- "entrance costs" criterion;

- criterion of additional benefits.

Criteria of attractiveness. He argues that the sector chosen for diversification needs to be attractive in terms of high returns on invested capital. Long-term profitability can serve as an indicator of attractiveness. It is also important for company owners to consider creating added value for shareholders. This means that in order to increase the profitability of the shares, the company has to go through the business areas that are better to operate in the general management of the company than to operate as an independent enterprise.

Criteria for "entrance costs". The cost of entering a new area of business should not impair the liquidity of the enterprise, thereby reducing its sustainability. Considering this problem in the model of "five forces of competition", M. Porter said that the risk of entry for new businesses entering attractive networks is always very high, as if it means buying an existing business or creating a new one from scratch.

An additional benefit criterion. Access to the new network will increase the sustainability of the enterprise, the new type of activity will lead to supporting the competitive advantage of the enterprise. If the company's activities meet these criteria, diversification is a priority strategic decision for enterprise management.

An important reason for enterprise diversification is to justify the fact that the prospects of the existing type of activity will not allow the company to achieve the desired level of labor productivity in the future. Sales growth, revenue and return on invested capital are the criteria for the level of labor 
productivity for a competitive company. Therefore, a reduction in the order portfolio or incomplete employment of production capacity may be the first signs of the need for diversification.

Research on the theory and practice of diversification K. Endryus, M. Gort, E. Esinara and S. It started with Berry's work. In this case, the object of research is diversification, which identifies opportunities to improve the structure of the enterprise, aimed at expanding the production industries, names and sales markets. For example, K. Andrews understood diversification as a change in the names of goods produced by individual enterprises and associations, an expansion in general terms. M. Gort understood diversification as the simultaneous servicing of several markets by companies. When Berry said diversification, he was referring to the growing number of industries in which the company operates. E.Esinara is the first to propose a radically different definition of diversification, showing its relationship to the level of risk as a strategy to reduce the risk of market activity in adverse conditions and increase the level of financial stability of the company.

CONCLUSION. In conclusion, the study of various forms of diversification of companies, their quantitative assessment has contributed to the emergence of strategic management theory as a new science.

\section{REFERENCES}

1. Масюк Н.Н. Концепция интегрированной адаптивной организации текстильного производства: монография[Текст]/ Иваново: Юнона, 2002-132с.

2. Аронов А.М. Диверсификация производства: теория и стратегия развития./А.М. Аронов, А.П. Петров- СПб.: Лениздат[Текст], 2000. -128 с.

3. Портер М. Конкуренция. М.: Изд. дом «Вильямс»[Текст], 2000

4. Topilovich, M. A. (2021). ECONOMIC EVALUATION OF MULTIPLICATIVE EFFICIENCY ON THE BASIS OF GENERALIZED INDICATORS OF RESOURCE COMPONENTS IN TOURIST RECREATION ACTIVITIES.

5. Рахимов, Д. Ш. (2021). САНОАТ ИҚТИСОДИЁТИДА МАХАЛЛИЙЛАШТИРИЛАЁТГАН МАХСУЛОТЛАРНИ ДИВЕРСИКАЦИЯЛАШ ОМИЛИ СИФАТИДА. Scientific progress, 1(6), 505-511.

6. Yoshinara E., Sakuma A., Itami K. Diversification strategy in Japanese company. - Tokyo, Nipon Keirai, 1979. - P. 27.

7. Мирзакаримова, М. М. (2013). Ногиронлар бандлиги муаммосини хал қилишда ижтимоий шериклик. Экономика и финансы (Узбекистан), (7). 
8. МИРЗаев, А. Т. (2021). ТЕОРЕТИЧЕСКИЕ АСПЕКТЫ РАЗВИТИЯ ПРОЦЕССОВ УПРАВЛЕНИЯ ТУРИСТСКО-РЕКРЕАЦИОННОЙ ДЕЯТЕЛЬНОСТЬЮ. Наука сегодня: фундаментальные и прикладные исследова, 19.

9. Raximov, D. S. (2021). DIVERSIFIKATSIYA HUDUDLAR SANOATNI MUVOZANATLI STRATEGIK RIVOJLANTIRISh YO ‘NALIShLARI. Oriental renaissance: Innovative, educational, natural and social sciences, $1(3), 199-207$.

10. Andrews K. The Concept of Corporate Strategy. - Homewood: Homewood University Press, 1971. - P.135.

11. Rahmonaliyevich, K. D. (2020). Choosing the optimal rule of monetary policy, taking into account changes in the main macroeconomic indicators. ACADEMICIA: AN INTERNATIONAL MULTIDISCIPLINARY RESEARCH JOURNAL, 10(12), 1351-1356.

12. Mirzakarimova, M. (2015). Arrangements of formation of effective employment in Uzbekistan. Spanish Journal of Rural Development, 6.

13. Urinov, A. G. A. (2003). ECONOMIC REFORMS IN UZBEKISTAN: SPECIFIC FEATURES, RESULTS AND PROBLEMS. Eurasian Vision: Felicitation Volume on the 70th Birthday of Prof. Devendra Kaushik, 187.

14. РахИМОВ, Д. Ш. (2020). ПЕРСПЕКТИВЫ РАЗВИТИЯ ОТРАСЛЕЙ ПРОМЫШЛЕННОСТИ УЗБЕКИСТАНА. In МИНТАҚА ИҚТИСОДИЁТИНИ ИНВЕСТИЦИЯЛАШНИНГ МОЛИЯВИЙХУҚУҚИЙ ВА ИННОВАЦИОН ЖИХАТЛАРИ (рр. 523-527).

15. Хакимов, А. Р. (2019). Стратегические задачи по развитию государственно-частного партнерства. Образование и наука в России и за рубежом, (16), 158-161.

16. Рахимов, А. (2019). Свободно-экономические зоны-расширение экспортного потенциала Узбекистана. Архивариус, (12 (45)).

17. Ahmadjanovich, U. A. (2021). The Main Ways To Improve The Efficiency Of Investment Activity For The Development Of Socio-Economic Processes. International Journal of Progressive Sciences and Technologies, 24(2), 197-205.

18. Mirzakarimova, M. (2018). Issues of providing employment in Uzbekistan. International Journal of Research in Social Sciences, 8(1), 523-538.

19. Ғойназаров, Ғ. А. (2021). КИЧИК МАКТАБ ЁШДАГИ БОЛАЛАРГА БЕРИЛАДИГАН ХАРАКАТЛИ ЎЙИНЛАР. Scientific progress, 2(1), 202-211.

20. Mirzakarimova, M. M., \& Baktiyor, K. (2020). Opportunities of getting demographic dividends in Uzbekistan. International Journal of Advanced Science and Technology, 29(8 Special Issue), 223235. 


\section{PEDAGOGY AND MODERN EDUCATION: TRADITION, EXPERIENCE AND INNOVATION}

Published: November 30, 2021 | Pages: 60-64

21. Khakimov, D. R. (2021). CREATING AN ADDITIONAL VALUE CHAIN IN THE PROCESS OF DIVERSIFICATION OF INDUSTRIAL LOCALIZATION. Oriental renaissance: Innovative, educational, natural and social sciences, 1(5), 243-248.

22. Yuldashov, I., \& Goynazarov, G. (2021). A NEED TO IMPROVE THE INSTITUTIONAL SYSTEM FOR INCREASING THE SOCIAL ACTIVITY OF YOUNG PEOPLE AT THE STAGE OF DEVELOPMENT. Интернаука, (12-3), 18-19.

23. УРИНОВ, А. А. (2020). СТРАТЕГИЧЕСКИЕ НАПРАВЛЕНИЯ ИННОВАЦИОННОЙ ПОЛИТИКИ. In МИНТАҚА ИҚТИСОДИЁТИНИ ИНВЕСТИЦИЯЛАШНИНГ МОЛИЯВИЙ-ХУҚУҚИЙ ВА ИННОВАЦИОН ЖИХАТЛАРИ (рр. 113-119). 


\title{
PREDOMINANCE, ELEMENTS AND BRAIN RESEARCH OF SPOUSAL SAVAGERY IN BANGLADESH: A SIMILAR REPORT ON COUNTRY METROPOLITAN ATTRIBUTES
}

\author{
Abdur Razzak \\ Assistant Teacher, University Of Rajshahi, Bangladesh
}

ABSTRACT: A few examinations have demonstrated that aggressive behavior at home against ladies, particularly savagery executed by a ladies' significant other is a difficult issue in Bangladesh. Accessible data from research showed that the most well-known kind of savagery against ladies in Bangladesh is aggressive behavior at home executed by cozy accomplices or ex-accomplices. In Bangladesh, the vast majority of the ladies experience aggressive behavior at home because of a cozy accomplice or relative in the course of her life.

KEYWORDS: Close accomplice brutality, Abusive behavior at home, country ladies, metropolitan ladies.

INTRODUCTION: Appearance of a notable inconsistent power connection between genders is a type of segregation and abuse of ladies which denies ladies' equivalent chance, security, confidence and nobility in the family and in the general public all in all. It is an exceptionally inescapable and genuine social disease in both created and agricultural nations. Independent of country's degree of improvement, ladies are powerless to double-dealing, mistreatment and sorts of disparaging savagery from men in all social orders where social standards, customs and general set of laws embrace ladies' sub-appointment to men. Profoundly inserted in social and financial practices, VAW is endorsed both by the general public and the State, for the sake of culture, custom and religion. In South Asian area, it starts some time before they are conceived and proceeds for the duration of their lives. Over the most recent couple of many years, it has arisen as the most squeezing and obstinate social issue across the local, social and social limits. The most pervasive type of VAW is aggressive behavior at home. In each nation where enormous scope studies have occurred, aggressive behavior at home against ladies has been viewed as by a long shot the most well-known, wide-spread and extensive type of sexual orientation based viciousness. 


\section{PEDAGOGY AND MODERN EDUCATION: TRADITION, EXPERIENCE AND INNOVATION}

Published: November 30, 2021 | Pages: 65-69

Ladies in Bangladesh are not a homogenous gathering; they have a place with the rich, center and helpless classes and are from various social and ethnic minority gatherings. They are likewise separated by rustic and metropolitan settings. SVAW is pervasive in both the associate-rustic and metropolitan. It is more articulated among the less fortunate and lessinstructed class. The purpose for this might be that-it is more straightforward to gain admittance to casualties having a place with lower financial layers. Nonetheless, in working class and higher monetary layers the spousal brutality is additionally continuous. In any case, the data about those consistently stays in dimness. Observational examinations observed that aggressive behavior at home is frequently utilized by men to set up and to implement their strength and non-populist sexual orientation standards, especially in the underlying long periods of marriage, and extremely young ladies might be especially helpless and unfit to stand up to. Men, baffled by neediness and social assumptions to accommodate their families, likewise respond with fierce conduct. Papers overflow with tales about spouses being killed or battered. It is said that in Bangladesh half of all killings are of spouses by husbands.

Brutality against ladies cuts across lines of pay, class, culture and home. Be that as it may, a few structures seem, by all accounts, to be more predominant in country regions, for example, youngster marriage, share and honor killings, corrosive tossing, oppressive language, beating, constrained sex and so forth ; others in metropolitan regions, like badgering, prudent and mental torment, rough sex, constrained prostitution, refusal to sex and so on There is a causal connection among SV and metropolitan viciousness, ascribed to changes in friendly controls, specifically the breakdown of social bonds. Now and then, separating of conventional joint families and formation of family units can be credited as new factors partner spousal viciousness.

Ladies of all financial layers are powerless against abuse and maltreatment by spouses, parents in law, and other relatives. A few investigations have shown that abusive behavior at home against ladies, particularly viciousness executed by a ladies' significant other is a major issue in Bangladesh.

In any case, sexual viciousness by spouse is more predominant in country regions (half) than metropolitan regions (37\%), as indicated by the study. Schuler distinguishes in a review 


\section{PEDAGOGY AND MODERN EDUCATION: TRADITION, EXPERIENCE AND INNOVATION}

Published: November 30, 2021 | Pages: 65-69

that $38 \%$ of ladies are beaten by their husbands in provincial spaces of Bangladesh. The figure appears to be a lot higher in metropolitan regions archiving 60\% of grown-up ladies battered by their significant other in Dhaka city.Yet, then again, a day to day existence history approach notices a lot higher greatness of the issue where $72 \%$ of ladies are seriously beaten by their husbands in some place of their life The event of actual maltreatment verifies the immensity of the issue, and simultaneously, validates the presence of obnoxious attack, which is expected to be high at family level. Ongoing review in country regions uncovers the degree of boisterous attack, which is incurred by $67 \%$ of spouses and $24 \%$ of relative.

In South Asia abusive behavior at home is an every day and regularly destructive unavoidable truth. Savagery against ladies is established in the man centric philosophy, which generally is answerable for the disguise of female inadequacy through a course of socialization, customs, strict laws and ceremonies. The legitimization and advancement of inflexible sexual orientation jobs, manliness, durability and male honor inside society sustains sex violence. The social powers that propagate sex based brutality can be seen from different methodologies viz: social qualities that will more often than not defend viciousness, general sets of laws that are not touchy to the privileges of ladies, financial frameworks that subordinate ladies and political frameworks that minimize ladies' need. Naved and Persson uncovered that in the two regions metropolitan and country, the most grounded factor related with husband's savagery against the life partner was the historical backdrop of maltreatment by the spouse's mom by his father. The review revealed that men seeing actual viciousness in the family during adolescence were occasions bound to truly mishandle the wife. Past openness to familial brutality presumably underwrites poor passionate advancement in the culprit, or may bring about reception of actual techniques as a method for adapting to struggle.

In Bangladesh conjugal viciousness against ladies are connected to ladies individual ascribes like age, schooling, monetary independence, strengthening, past exploitation and history of level of financial imbalance among people, the degree of more distant family, savagery in parental family. Accomplice's ascribes incorporates age, schooling, work, utilization of liquor and medications history of viciousness in parental family, level of correspondence with her. Diverse social and conduct characteristics like age, training, financial status, family design, 


\section{PEDAGOGY AND MODERN EDUCATION: TRADITION, EXPERIENCE AND INNOVATION}

Published: November 30, 2021 | Pages: 65-69

religion and so forth are likewise connected with DV. Exploration uncovers that spouse's age and conjugal length are related with brutality's more youthful ladies are more in danger of DV than the more seasoned women and longer the conjugal association lesser the savagery. Subsequently, youngster marriage, which is exceptionally normal in rustic regions, adds to the high pace of the continuation of SV. However broad supposition that will be that ladies' expanding job to showcase economy increment ladies' independence and engage them in the family and society, scientists observed that freedom and independence trigger new types of brutality because of social response against their infringement of customary male centric normal practices, control of resources and profit, their dissent of uncalled for double-dealing and discrimination Psychopathology, substance misuse, neediness, social elements, outrage, stress and discouragement regularly are thought to cause SV.

CONCLUSION. Spousal viciousness in Bangladesh is a central issue of advancement mediations just as in common liberties viewpoints. Because of SV the home of a ladies which should have been a glad and eminent home with loaded with adoration and love, transforms into hellfire. This isn't useful for the sound advancement of a nation. Spousal savagery obstacles ladies' prosperity and over all turn of events, for example it has direct ramifications for ladies' wellbeing physical, mental, sexual and regenerative just as financial expenses, and a while later unfavorable consequences for mental advancement of youngsters.

\section{REFERENCES}

1. Jensen, E., \& Jensen, H. (2011). Dialog s starši [Dialogue with parents]. Ljubljana: Inštitut za sodobno družino Manami.

2. Katherine Paul. Hillary Clinton: It's time to dump Monsanto and support public health, and regenerative, organic agriculture. Retrieved 19/12, 2014.

3. Jejeebhoy S.(1998) Associations between wife-beating and fatal and infant death: Impression from a survey in rural India. Stud family planning, 29: 300-8. 
Published: November 30, 2021 | Pages: 65-69

4. Wahed T, Bhuiya A; (2007) Battered bodies and Shattered Minds: Violence against Women in Bangladesh; Indian J Med Res 126. Pp341-354; ICDDR,B.

5. Schuler, S.R, S.M. Hashemi and S.H. Badal (1998) Man's violence against women in Bangladesh: undermined or exacerbated by microcredit programmes?\| Development in practice, $8(2) 148-157)$ 


\section{FORMATION OF MONEY TRANSMISSION MECHANISMS TO INCREASE THE EFFICIENCY OF MONETARY POLICY}

\section{Dilshonjon Xakimov \\ Candidate of Economic Sciences, Fergana State University, Uzbekistan}

ABSTRACT: The article examines some approaches to monetary policy. Assessing the effectiveness of monetary policy, the most well-known rules of monetary policy are given.

KEYWORDS: monetary policy, macroeconomic processes, refinancing rate, potential indicator.

INTRODUCTION: As a result of measures taken by the monetary authorities, low inflation rates, moderate devaluation of the national currency, stability of the banking system were ensured. However, despite the positive results achieved, there are still problems and factors that hinder the effectiveness of monetary policy in Uzbekistan and its effective impact on economic processes. In particular, there is a need to further increase the level of non-inflationary monetization of the economy, to reduce the extra-budgetary circulation of cash. In addition, there are large differences in exchange rates, which reduce the ability of monetary authorities to influence the economy through currency regulation, making it difficult for money transfers to operate.

THE MAIN FINDINGS AND RESULTS. This situation means that it is important to determine the type and direction of interactions between macroeconomic indicators, the channels in which they operate. This allows the necessary adjustments to the policy being made in a timely and expeditious manner. The development and implementation of comprehensive measures to maintain macroeconomic stability will help to prevent negative impacts in the event of changes in external conditions and increase the effectiveness of monetary policy.

The use of the rule in the implementation of monetary policy leads to a number of positive results. It is advisable for the Central Bank to use the Taylor model in minimizing losses, as in this case the monetary authorities can use the necessary monetary instruments at will. The Taylor model assumes that monetary aggregates and exchange rate targeting are compatible. The table below lists the most well-known rules of monetary policy. 
PEDAGOGY AND MODERN EDUCATION: TRADITION, EXPERIENCE AND INNOVATION

Published: November 30, 2021 | Pages: 70-74

Table 1. The most well-known rules of monetary policy

\begin{tabular}{|c|c|c|c|}
\hline Year & The name of the rule & Rule equation & Authors \\
\hline $1600-y$. & Fixed exchange rate rule & $\Delta \mathrm{e}_{\mathrm{t}}=0$ & - \\
\hline 1898 & $\begin{array}{c}\text { Interest rate rule for the } \\
\text { management of the } \\
\text { "rational monetary } \\
\text { system" }\end{array}$ & $\mathrm{i}_{\mathrm{t}}=\mathrm{bp}_{\mathrm{t}}$ & K. Viksel \\
\hline 1920 & Fisher's rule & $\Delta \mathrm{e}_{\mathrm{t}}=-\Delta \mathrm{p}_{\mathrm{t}-1}$ & I. Fisher \\
\hline 1953 & $\begin{array}{l}\text { The rule of constant } \\
\text { growth rate of money } \\
\text { supply }\end{array}$ & $\Delta \mathrm{m}_{\mathrm{t}}=\mathrm{const}$ & M. Friedman \\
\hline $1983-1985$ & $\begin{array}{l}\text { Targeting rule of } \\
\text { nominal income }\end{array}$ & $y_{t}=0$ & Ch. Bin, R. Hall \\
\hline 1992 & Gulhart rule & $\begin{array}{c}\mathrm{i}_{\mathrm{t}}=\mathrm{a}+\mathrm{b} \mathrm{p}_{\mathrm{t}} \\
(\mathrm{a}=0,03, \mathrm{~b}=1,5)\end{array}$ & Ch. Goodhart \\
\hline 1993 & Taylor's rule & $\begin{array}{c}\mathrm{i}_{\mathrm{t}}=\mathrm{b} \mathrm{p}_{\mathrm{t}}+\mathrm{cy} \mathrm{y}_{\mathrm{t}} \\
(\mathrm{b}=1,5, \mathrm{c}=0,125)\end{array}$ & Dj. Taylor \\
\hline 1999 & Ball rule & $\begin{array}{c}i_{t}=b p_{t}+c y_{t}+d_{1} q_{t}++d_{2} q_{t-1} \\
\left(b=2,51, c=1,93, d_{1}=0,43, d_{2}\right. \\
=0,3)\end{array}$ & L. Boll \\
\hline
\end{tabular}

Here, it - change in nominal short-term interest rate. Pt - $t$ deviation of inflation from the optimal indicator over time. $Y t-t$ deviation of GDP relative to the potential indicator at the time. $\Delta$ et $-\mathrm{t}$ change in the nominal exchange rate over time. $\Delta \mathrm{mt}-\mathrm{t}$ the nominal rate of increase in the money supply over time. qt - t real exchange rate at the time.

The rules of monetary policy have been given many definitions by economists. Moiseev S.R. According to him, the most accurate definition is: "The rule of monetary policy is a function of the response of the Central Bank, according to which the application of the monetary policy instrument is carried out in response to changes in important economic indicators."

For decades, Friedman has advocated the implementation of the rule of increasing the money supply set by the Federal Reserve at the rate of 3-5 percent. However, when the FZT tried to apply money-based rules in the early 1980s, the move did not yield positive results: the stability of short-term interactions between the money supply and the economy was very low, so it was clear that such rules could not be a reliable target for monetary policy. Taylor's rule appears as a simple equation. This equation was proposed by Taylor in 1992 to describe the reaction of the FZT target interest rate to inflation and economic cycles. 


\section{PEDAGOGY AND MODERN EDUCATION: TRADITION, EXPERIENCE AND INNOVATION}

Published: November 30, 2021 | Pages: 70-74

This equation has successfully performed both descriptive and instructional functions.

According to the equation, the FZT followed the two views from 1987 to 1992, setting the level of the instrument of its policy, the rates on federal funds.

First, how much the inflation rate in the U.S. is close to 2 percent. If inflation exceeds the 2 percent level, the FZT has raised interest rates on federal funds to curb inflation.

Second, how far the real income of the economy is from the potential indicator. If the income is lower than the potential figure, the FZT has lowered the target interest rate in order to stimulate the economy.

At present, the excess of interest rates over a proportional change in relation to inflation is called the Taylor principle.

Taylor also showed that between 1987 and 1992, the equation described the exact movement of the rate on federal funds. According to Taylor, the successful results of the monetary policy of that period, which is now recognized, were achieved due to the lack of clear adherence to such a rule.

CONCLUSION. Like the Phillips curve, the Taylor curve shows the interrelationship between inflation and unemployment. However, if the Phillips curve shows the relationship between inflation and unemployment as a postulate, Taylor has shown that policymakers work with a compromise between inflation and unemployment variability. The effective policy of the Central Bank will allow for a better compromise by reducing not only the volatility of inflation, but also the volatility of unemployment.

\section{REFERENCES}

1. Усоский В.Н. Ограничения на выбор режима денежно-кредитной политики. Сборник Белорусского государственного экономического университета..- Минск, 2008. -С. 15.

2. Моисеев С.Р. Правила денежно-кредитной политики//Финансы и кредит.- Москва, 2008. - №8.- C. 12.

3. TaylorJ.B., 1993. Discretionversus policy rules in practice. Carnegie-Rochester Conference Series on Public Policy 39. 


\section{PEDAGOGY AND MODERN EDUCATION: TRADITION, EXPERIENCE AND INNOVATION}

Published: November 30, 2021 | Pages: 70-74

4. Рахимов, А. Ш. (2021). САНОАТ ИҚТИСОДИЁТИДА МАХАЛЛИЙЛАШТИРИЛАЁТГАН МАХСУЛОТЛАРНИ ДИВЕРСИКАЦИЯЛАШ ОМИЛИ СИФАТИДА. Scientific progress, 1(6), 505-511.

5. Rahmonaliyevich, K. D. (2020). Choosing the optimal rule of monetary policy, taking into account changes in the main macroeconomic indicators. ACADEMICIA: AN INTERNATIONAL MULTIDISCIPLINARY RESEARCH JOURNAL, 10(12), 1351-1356.

6. Мирзакаримова, М. М. (2013). Ногиронлар бандлиги муаммосини хал қилишда ижтимоий шериклик. Экономика и финансы (Узбекистан), (7).

7. Raximov, D. S. (2021). DIVERSIFIKATSIYA HUDUDLAR SANOATNI MUVOZANATLI STRATEGIK RIVOJLANTIRISh YO 'NALIShLARI. Oriental renaissance: Innovative, educational, natural and social sciences, 1(3), 199-207.

8. Хакимов, А. Р. (2019). Стратегические задачи по развитию государственно-частного партнерства. Образование и наука в России и за рубежом, (16), 158-161.

9. Mirzakarimova, M. (2015). Arrangements of formation of effective employment in Uzbekistan. Spanish Journal of Rural Development, 6.

10. РахИМОВ, Д. Ш. (2020). ПЕРСПЕКТИВЫ РАЗВИТИЯ ОТРАСЛЕЙ ПРОМЫШЛЕННОСТИ УЗБЕКИСТАНА. In МИНТАҚА ИҚТИСОДИЁТИНИ ИНВЕСТИЦИЯЛАШНИНГ МОЛИЯВИЙ-ХУҚУҚИЙ ВА ИННОВАЦИОН ЖИХАТЛАРИ (рр. 523-527).

11. Mirzakarimova, M. (2018). Issues of providing employment in Uzbekistan. International Journal of Research in Social Sciences, 8(1), 523-538.

12. ХакимОв, А. Р. (2021). ХУДУД САНОАТИНИ ДИВЕРСИФИКАЦИЯ ҚИЛИШ ОРҚАЛИ РАҚОБАТБАРДОШЛИГИНИ ОШИРИШ ИМКОНИЯТЛАРИ. Scientific progress, 2(1), 631638.

13. Рахимов, А. (2019). Свободно-экономические зоны-расширение экспортного потенциала Узбекистана. Архивариус, (12 (45)).

14. Yuldashov, I., \& Goynazarov, G. (2021). A NEED TO IMPROVE THE INSTITUTIONAL SYSTEM FOR INCREASING THE SOCIAL ACTIVITY OF YOUNG PEOPLE AT THE STAGE OF DEVELOPMENT. Интернаука, (12-3), 18-19.

15. Khakimov, D. R. (2021). CREATING AN ADDITIONAL VALUE CHAIN IN THE PROCESS OF DIVERSIFICATION OF INDUSTRIAL LOCALIZATION. Oriental renaissance: Innovative, educational, natural and social sciences, 1(5), 243-248. 


\section{PEDAGOGY AND MODERN EDUCATION: TRADITION, EXPERIENCE AND INNOVATION}

Published: November 30, 2021 | Pages: 70-74

16. Ғойназаров, Ғ. А. (2021). КИЧИК МАКТАБ ЁШДАГИ БОЛАЛАРГА БЕРИЛАДИГАН ХАРАКАТЛИ ЎЙИНЛАР. Scientific progress, 2(1), 202-211.

17. Umarov, O., \& Khakimov, D. (2020). CONCEPT OF GUARANTEED DEVELOPMENT OF ENCLAVE TERRITORIES. Экономика и социум, (6), 265-268.

18. Хакимов, Д. Р., \& Рахмоналиев, Н. А. (2020). Mintaqaviy investitsiyalar: Maqsadlar, muammolar va ularni hal qilish. In МИНТАҚА ИқТИСОДИЁТИНИ ИНВЕСТИЦИЯЛАШНИНГ МОЛИЯВИЙ-ХУҚУҚИЙ ВА ИННОВАЦИОН ЖИХАТЛАРИ (рр. 494-498). 
PEDAGOGY AND MODERN EDUCATION: TRADITION, EXPERIENCE AND INNOVATION

Published: November 30, 2021 | Pages: 75-79

\section{EXAMINATION ON THE SHOWING MODEL OF COLLEGE PC ESTABLISHMENT DEPENDENT ON MOOC MIXED LEARNING}

\section{Xianfa Cao \\ Xianfa Cao \\ College Of Mathematics And Computer Science, Dalian University Of Technology, China}

ABSTRACT: This paper takes the College PC Establishment course for instance, attempting to construct a mixed learning model dependent on MOOC. Through the mix of MOOC internet learning and conventional homeroom, this paper plans to tackle the issues of single learning mode in customary study hall, which isn't helpful for understudies' customized learning, to viably upgrade understudies' learning drive, animate learning interest, further develop showing impact, and give novel plans to showing change in Schools and Colleges.

KEYWORDS: College PC Establishment, mixed learning model.

INTRODUCTION: With the assistance of globally prestigious colleges and its solid school personnel, it broke the obstructions of existence, and aided a huge number of understudies from everywhere the world understand the craving to procure the substance of information and offer the high level instructive assets. As another showing mode, MOOC coordinates the benefits of free showing assets, intuitive experience among instructors and understudies, and productive criticism. Its reality not just adequately advances the change of customary advanced education, yet in addition brings new freedoms for the change of advanced education instructing. In this paper, taking the "College PC Establishment" course for instance, we attempt to assemble a blended learning mode dependent on MOOC. The intention is to change the current circumstance of customary instructing, like the single show of showing structures and learning assets, and the absence of correspondence among educators and understudies.

Current circumstance obviously showing The course of "College PC Establishment" is wealthy in content, wide in inclusion and solid practically speaking. It is a course consolidating hypothesis and practice. Be that as it may, because of the absence of absolute class hours, understudies need to completely dominate fundamental information and down to earth 


\section{PEDAGOGY AND MODERN EDUCATION: TRADITION, EXPERIENCE AND INNOVATION}

\section{Published: November 30, 2021 | Pages: 75-79}

activity abilities, which is restricted simply by the learning in class. Through the investigation of this course, we track down that there are a few issues in the current educating. There are incredible contrasts in understudies' PC learning establishment. New understudies have a specific capacity to apply data innovation, however there are extraordinary contrasts in the general level. Due to the significant weight of instructors and the weighty substance of courses, educators need to zero in on the understudies in the fundamental center school. The understudies with great establishment and helpless establishment have not been given designated direction, which prompts the understudies with great establishment not being advanced, while the understudies with helpless establishment have not been tackled on schedule despite tremendous learning hardships, so they progressively lost interest in learning PC courses. If we don't consolidate the qualities of understudies and keep on taking on a bound together beginning stage of showing thinking, then, at that point, showing understudies as per their inclination resembles discussing fighters on paper, and the genuine impact isn't acceptable Educators' showing techniques are single and inappropriate. Great showing content requirements legitimate training strategies to be acknowledged by more understudies. A similar showing content, utilizing diverse showing techniques, its showing impact is additionally totally different. As of now, albeit numerous educators utilize current showing strategies like mixed media to instruct, however indeed, they just present the substance initially composed on the slate before the understudies in PPT, and the showing strategy has not changed considerably. In the study hall, the fundamental substance is to clarify the information points of the showing materials, and the chances for understudies to rehearse and work are not many, which is entirely negative for understudies to dominate information. Taking the course of "College PC Establishment" for instance, is the objective of this course "information or thinking"? Assuming that we basically talk about information, it could be extremely basic and exhausting, and there are an excessive number of information focuses, and we can't complete it just when of class. For instance, the substance of twofold predominantly incorporates mathematical worth, change of various number frameworks, marked and unsigned number, unique code, supplement code, estimation dependent on paired framework, and so on it needs a few class hours to instruct. 


\section{PEDAGOGY AND MODERN EDUCATION: TRADITION, EXPERIENCE AND INNOVATION}

Published: November 30, 2021 | Pages: 75-79

\section{Examination of constructivism}

The hypothesis of constructivism is understudy focused. Educators make learning circumstances, give understudies rich and customized learning materials, direct and elevate understudies to effectively investigate and find information, to finish the dynamic development of information. The use of MOOC's half breed learning mode gives understudies full time authority and free power, elevates understudies to concentrate autonomously on the extraordinary $M O O C$ stage, understands the sharing of showing assets, and gets through the impediment of general setting.

\section{Examination of organization learning hypothesis}

Organization learning is a sort of learning through PC organization. Through the organization stage, it can do autonomous learning, develop understudies' capacity of finding and taking care of issues, gathering, dissecting and utilizing data. Schools and colleges transfer the showing assets identified with the course of college PC establishment to the MOOC stage. Understudies can find and utilize the learning assets as indicated by the necessities of the stage to understand the learning techniques for internet learning, online correspondence and online input, and further develop the learning quality and instructing impact.

Prior to doing blended learning exercises, instructors need to dissect and decipher the fundamental circumstance of the course exhaustively, consider whether the execution of the model in the course is proper, and regardless of whether the execution of learning exercises is smooth, so the early investigation stage is vital. Investigation of student In the entire showing process, homeroom exercises have a place with understudies, movements of every kind ought to be around the focal point of understudies. Thusly, instructors need to comprehend the understudies' unique information hold, learning side interests, extracurricular learning climate, the capability of utilizing MOOC stage, individual learning disposition towards mixed learning, and so forth 


\section{PEDAGOGY AND MODERN EDUCATION: TRADITION, EXPERIENCE AND INNOVATION}

Published: November 30, 2021 | Pages: 75-79

Prior to the start of blended learning exercises, instructors basically through poll study and base test to comprehend the first information hold of understudies, arrange understudies to make a class QQ bunch correspondence stage for understudies to convey. The exercises in class for the most part incorporate the accompanying three connections.

\section{Learning in class}

Distinguish the issue. In the homeroom, instructors dissect and sum up the troubles and issues in understudies' independent learning input, gather the issues that most understudies view as hard to comprehend and have investigation esteem, and convey and talk about with understudies, in order to assist understudies with dominating the information all the more solidly. Independent request. Subsequent to advancing request questions, instructors should initially establish a customized learning climate for understudies, in other words, understudies should initially lead free request, and afterward educators should carry out a "coordinated" showing technique for understudies' concerns experienced during the time spent independent request, give exact direction to understudies, and assist understudies with tackling the riddles experienced in disguising information and uniting request Gathering participation. Subsequent to providing understudies with a specific measure of time to investigate autonomously, instructors ought to arrange understudies to talk about in gatherings, so that gatherings can take care of certain issues in collaboration, so understudies can clarify the thoughts of taking care of issues in the conversation, in order to accomplish the reason for taking care of issues. The perspective of every understudy is very unique. The investigation of issues through bunch collaboration is helpful for gaining from one another and working on together.

CONCLUSION. In the customary study hall, learning assessment has various capacities as indicated by the hour of execution. As a rule, learning assessment can be separated into three sorts: analytic, developmental and summative. Analytic assessment typically assists instructors with understanding the first information on various understudies and their benefits and hindrances before the start of the course, in order to make a superior educating plan. Educators for the most part utilize the blend of base tracking down test and past scores. Developmental evaluation generally happens in the study hall, and accepts unit as the 


\section{PEDAGOGY AND MODERN EDUCATION: TRADITION, EXPERIENCE AND INNOVATION}

Published: November 30, 2021 | Pages: 75-79

fundamental module for testing. Its fundamental capacity is to assist teachers with precisely getting a handle on the continuous learning circumstance of understudies, and afterward give viable assistance. It can likewise assist instructors with observing issues in the past educational program instructing and right them on schedule. An overall test strategy remembers for class test, unit test, and so forth The summative assessment happens after the execution of the entire showing plan, which is the general assessment of the learning accomplishments of understudies and educators in the entire learning process.

\section{REFERENCES}

1. Whitelock, D. (2012). Innovating Pedagogy 2012: Open University Innovation Report 1. Milton Keynes, UK, The Open University. http://www.open.ac.uk/blogs/innovating (Accessed 30 September 2012.)

2. Cochrane, T. (2007). Mobile web2 pedagogies. In D. Parsons \& H. Ryu (Eds.), Proceedings of the Conference on Mobile Learning Technologies and Applications.

3. Miangah, T., \& Nearat, A. (2012). Mobile-assisted language learning. International Journal of Distributed and Parallel Systems, 3 (1), 309-319.

4. Anderson, K., \& Nielsen, C. (2001). GMOs, the SPS Agreement and the WTO. The Economics of Quarantine and the SPS Agreement, 305.

5. John A. Duffie, William A. Beckman Solar Engineering of Thermal Processes, NY 2006. 


\title{
CONCEPTUALIZING SCHOOL UPGRADES ASPECT INSIDE THE SETTING OF SCHOOL-BASED ADMINISTRATION
}

\author{
Hainun Nisa \\ Department Of English Education, Trisakti University, Indonesia
}

\begin{abstract}
School Based Administration has a solid accentuation on neighborhood navigation to guarantee successful and ceaseless school improvement. There should be a solid spotlight on further developed learning accomplishments for all understudies. For this to happen viably, administrators, school panels and boss need to ceaselessly screen and assess school execution. School Based Administration isn't an end in itself except if it can assist with cultivating a further developed school culture, greater choices coordinated to progress or more all, upgrades in kids' learning
\end{abstract}

KEYWORDS: School, The executives, Improvement, Powerful, Independence, Advancement.

INTRODUCTION: This paper manages the conceptualizing school enhancements aspect inside the setting of School Based Administration. The basic segment of the paper portrays the hypothetical points of view and the events of the theoretical structure of School-based Administration. Also, it followed by clarification about the central issues of value improvement with regards to school incorporated turn of events. This paper additionally features the job of the head in fruitful School Based Administration more meticulously. Moreover, the meaning of the school culture in supporting the school improvement will likewise be introduced. At long last it momentarily clarifies the technique and approach just as the methodology to carry out the arrangement of school coordinated turn of events.

The Idea and Practice of a School-Based Administration

School Based Administration (SBM) is an elective type of overseeing schools where they include more extensive expert in settling on choices inside the public training strategy system. Besides, the objectives of School Based Administration are to:

(1) work on the nature of instruction;

(2) form the limit of administrators as school pioneers and directors; 


\section{PEDAGOGY AND MODERN EDUCATION: TRADITION, EXPERIENCE AND INNOVATION}

\section{Published: November 30, 2021 | Pages: 80-83}

(3) form local area interest;

(4) form the soul of accomplishment in understudies and educators across schools;

(5) empower choices to be made at the nearby level dependent on neighborhood needs

The decentralization of instruction empowers the school to have the power to arrange an expanded extent of school the board. Over the long run, expanded monetary assets will be accessible to schools. The school has the power to settle on significant choices like the administration of the spending plan, obtainment of offices and enrolling privileged educators. Schools are all around put to settle on these choices with their neighborhood information on the necessities of their kids. The encompassing local area will take part in setting needs and dynamic when, for instance, the school building/rooftop is broken after a rainstorm, or on the other hand if the school has an absence of educators. The people group can quickly run after tracking down arrangements.

There should be a solid spotlight on further developed learning accomplishments for all understudies. For this to happen successfully, directors, school councils and pengawas (administrator) need to constantly screen and assess school execution. School Based Administration isn't an end in itself except if it can assist with encouraging a further developed school culture, more excellent choices coordinated to progress or more all, enhancements in kids' learning.

The school improvement plan is the device that the school uses to zero in on further developing execution. It shapes a coordinated preparation, checking, revealing and survey process. It permits a school to foster its own instructive plans and needs. It gives an observing and announcing system to permit a school to keep an eye on its encouraging and, all the more especially, to set up whether its goals are meet.

A critical device in successful school improvement is the assortment and investigation of information. Information ought to be examined inside the setting of the school and used to foster school improvement procedures. Information ought to be kept and disaggregated on:

(a) understudy learning;

(b) understudy participation; 


\section{PEDAGOGY AND MODERN EDUCATION: TRADITION, EXPERIENCE AND INNOVATION}

\section{Published: November 30, 2021 | Pages: 80-83}

(c) understudy conduct;

(d) assignment of monetary assets;

Directors assume a key part in setting class sizes, class courses of action, checking the long periods of training kids get, and allotting assets which sway on the learning. This is done through discussion. Schools can look for the help of their pengawas (chief) to help improvement. Pengawas notice numerous homerooms and schools and have a wide information on great and helpless practice. Pengawas would then be able to impart to their schools, different improvement thoughts acquired from their experience and from other pengawas, and schools.

School panels are associated with and support their schools. School panels can help with advancing groundbreaking thoughts locally. School panels have significant and important contribution with choices on school arranging and assets. School advancement should be quality situated and give further developed training to all.

Both of these choices would let loose educators and rooms. The educators may then be utilized to help understudies encountering trouble, give group instructing, or give extra proficiency support. Anyway proficient help and preparing will be needed for the educator instructing multi-grade classes interestingly.

The chief assumes a key part in driving the school local area to foster vision, mission, objectives and arranging. The chief is a vital figure in social affair the perspectives on the local area and drawing agreement sees from partners. These perspectives cover all parts of school the executives including educating, understudy prosperity and conduct, money and offices. Moreover, the chief is the critical innovator in further developing educational program, instructing and learning.

CONCLUSION. The course of instructive decentralization in Indonesia assigns a portion of the expert in training to districts to settle on choices about spending plan allotment, advancement, school area, instructor enlistment, head choice and arrangement, educator preparing, and 


\section{PEDAGOGY AND MODERN EDUCATION: TRADITION, EXPERIENCE AND INNOVATION}

\section{Published: November 30, 2021 | Pages: 80-83}

nearby educational program assurance. Decentralization of tutoring is an intricate interaction, which can carry critical change to educational systems, enabling schools to make arrangements; gain assets; spend the financial plan; foster instructor preparing; give educator proficient turn of events and foster educational program. School Based Administration has a solid accentuation on neighborhood direction to guarantee compelling and ceaseless school improvement. There should be a solid spotlight on further developed learning accomplishments for all understudies. For this to happen viably, administrators, school boards and pengawas need to persistently screen and assess school execution.

\section{REFERENCES}

1. Ruan, J. (2003). A Study of Bilingual Chinese/English Children's Code Switching Behavior. Academic Exchange Quarterly, 7 (1), 142-147.

2. Garcia, O., \& Wei, L. (2014). Translanguaging: Language, bilingualism and education. Basingstoke: Palgrave Macmillan.

3. Briggs, K.L., \& Wohlstetter, P. (2003). Key elements of a successful school-based management strategy. school effectiveness and school improvement: An International Journal of Research, Policy and Practice, 14(3).

4. Kelehear, Z. (2006). The art of successful school-based management. The interstate school leaders licensure consortium (ISLLC) Standards for School Leaders.

5. Geng Yu, yuan Siqiang. Research on computer basic curriculum reform of MOOC $+\mathrm{SPOC}$ Hybrid Teaching Mode under the guidance of computational thinking [M]. China business press, August 2018. 


\title{
SYSTEMS OF POWERFUL DESIGNING PLANT UPKEEP AND ITS SUGGESTIONS ON MODERN AND MONETARY DEVELOPMENT OF A NON-INDUSTRIAL COUNTRY
}

\author{
Atakpu E Dennis \\ Faculty Of Science And Technical Education, River State University Of Science And Technical, \\ Nigeria
}

ABSTRACT: This article uncovered the reasons for designing plant disappointment. Reevaluated preventive, remedial/closure and prescient support methodologies considering the predominant upkeep approaches in a contemporary designing and non-industrial country, in a bid to proffer viable support techniques that will give a satisfactory degree of plant activity. It viewed support as a training that is completed after identification of an irregularity and pointed toward reestablishing ordinary working conditions.

KEYWORDS: support, upkeep techniques, viable support, non-industrial country, preventive upkeep.

INTRODUCTION: Upkeep the executives in a mechanically non-industrial country like Nigeria should begins the task planning phase. Choosing an upkeep the board system when the gear is introduced may not give a successful outcome. Designing plant upkeep is an administration practice that is utilized to boost creation and limit misfortune and waste. In this way, choosing an effective upkeep system requires a decent information on gear disappointment conduct and support the board rehearses. When you like why gear fizzles, how hardware falls flat and when hardware bombs one can positively choose the right blend of upkeep techniques to broaden and expand its administration and execution.

\section{Reasons for plant disappointment}

In a non-industrial country like Nigeria, definitely realize that anything strong can be broken or will fall apart. There are typically blends of causes that can make a piece of hardware fall flat. These can be classified into a couple of basic clarifications. 


\section{PEDAGOGY AND MODERN EDUCATION: TRADITION, EXPERIENCE AND INNOVATION}

Published: November 30, 2021 | Pages: 84-86

1. Over-focused on Parts: Actual matter can just get by inside a restricted scope of forced anxieties and conditions. Whenever matter is focused on past its perseverance it will unexpectedly fizzle. Some normal models are over-burdening, turning out to be excessively hot and setting a thing under fluctuating powers prompting weakness circumstances.

2. Helpless Plan Decisions or potentially Helpless Assembling/Get together Quality: this as the heading suggests there are times when a section is made erroneously, fabricated inaccurately or its plan couldn't withstand the forced assistance obligation. Plan blunders incorporate choosing small hardware, wrongly indicated parts and presenting dangers. Assembling blunders like helpless welding, helpless projecting, inaccurately situated openings and out of resilience machining are genuine conceivable outcomes. Also, get together mistakes, for example, under-force on bolts, ineffectively fitted electrical associations and easy route gathering quality practices will ultimately prompt hardware disappointment.

The term plant incorporates extremely durable and semi super durable design just as things like machines, lab hardware, the slate or blackboard, and the student and instructor devices. Adebayo characterized compelling plant upkeep as typically alludes to the techniques, methodologies, and practices used to keep a modern processing plant running proficiently. This can incorporate anything from standard checks of gear to making them work appropriately, to cleaning trash receptacles and latrines. The overall point of plant support is to establish useful work space that is additionally alright for laborers. In any case, there is a prerequisite to work on a comprehension of the essential impression of the upkeep job. Here, it is relevant to take note of that the support work has gone through genuine change over the most recent thirty years.

CONCLUSION. This is an essential support arranging that should begin the planning phase. When a thing of plant is assembled you are left with this procedure. A piece of hardware requires what upkeep it needs to keep up with its exhibition. There is no explanation getting away from the way that the plan determines the support prerequisites. Precautionary upkeep methodologies are the best since they are the most affordable method for diminishing support. Their magnificence and marvel is that they are a hardware lifetime procedure that brings persistent better activity for the types of gear whole working life. 


\section{PEDAGOGY AND MODERN EDUCATION: TRADITION, EXPERIENCE AND INNOVATION}

Published: November 30, 2021 | Pages: 84-86

Individuals can possibly change their conduct and considerations when they track down better ways of acting and think. When an individual realizes common decency to do, they will no doubt do it. Obliviousness is colossally costly! One of the most amazing upkeep methodologies is to show the designing plan necessities of the gear to the administrators and maintainers who will run and really focus on it. This is a sound vital advance since it implies key information is moved to the clients of the hardware.

\section{REFERENCES}

1. Baće, M., Ilijić, S., Narancić, Z., Bistricić, L. (2002). The envelope of projectile trajectories. European Journal of Physics. 23, 637-642.

2. Knezevich, S.J. (1975). Administration of public education. New York: Harper and Row Publishers.

3. Khan, K.A.; Rhodes, C.T. Effect of variation in compaction force on properties of six direct compression tablet formulations. Journal of Pharmaceutical Sciences. 65(12), 1835-1837, 1976.

4. Callister, W. D., \& Rethwisch, D. G. (2007). Materials science and engineering: an introduction (Vol. 7, pp. 665-715). New York: Wiley.

5. Chudinov, P.S. (2004). Analytical investigation of point mass motion in midair. European Journal of Physics. 25, 73-79.

6. Rollag M. D, Berson D. M, Provencio I. 2003. Melanopsin, Ganlion-cell photoreceptors and mammalian photoentrainment. Journal of biological rhythms (2003), 18/3, 227-234. 


\title{
EVALUATION OF LEFTOVER BURDENS BECAUSE OF COLD BOWING PRIMARY STEEL SUPPORTS UTILIZING LIMITED COMPONENT DISPLAYING
}

\author{
Jordi Miro \\ Assistant Professor, Bourj International College, Lebanon
}

\begin{abstract}
This paper centers around surveying the size of these leftover anxieties for an exclusive virus bending strategy utilizing nonlinear limited component investigation. The impact of fluctuating a portion of the key boundaries (for example extent of applied burdens, stacking grouping and separating between end upholds) on leftover anxieties is then examined and proposals are recommended for actuating pragmatic scopes of shapes with adequate cutoff points for lingering stresses.
\end{abstract}

KEYWORDS: support, upkeep techniques, viable support, non-industrial country, preventive upkeep.

INTRODUCTION: The virus bowing cycle isn't yet generally took on in the steel business for bending steel plate braces particularly for applications requiring tight ebbs and flows because of conceivable breaking and restricted harm of the steel area in the plastic reach. On the other hand, cut bending and hotness bending are for the most part utilized particularly for bending steel span plate braces. Since cold twisting depends on plastic strains, remaining anxieties create in the steel area subsequent to bowing. Actually, lingering stresses exist in straight created braces, particularly if hot-rolled, because of warm impacts as the segment is chilled off. The impact of lingering weights on the conduct of steel individuals in help (after creation) isn't immaterial and their impacts fluctuate contingent upon their wellspring of beginning and dispersion in the cross segment. Lingering stresses that form in the straight manufactured support has been broadly investigated and fused in the plan strategy and norms for steel development.

The exclusive framework is straightforward as it independently twists the top and base ribs of the brace at different segments along its length by applying mechanical powers in the plastic 


\section{PEDAGOGY AND MODERN EDUCATION: TRADITION, EXPERIENCE AND INNOVATION}

Published: November 30, 2021 | Pages: 87-90

reach utilizing pressure driven jacks worked in a mobile edge. Thusly, the ideal bended shape creates as a progression of short straight portions. The principle boundaries of the virus bowing framework are the extent of the sidelong twisting burdens, the spans' length and the separating of the supporting arms of the mobile casing. A two-dimensional scientific arrangement was inferred to decide these boundaries and screen the mathematical state of the distorted steel brace after each heap application with the goal that the ideal and incited bended shapes are in understanding. Results from the scientific strategy were approved by examination with test information for a full-scale steel brace that was tried at the US steel fabricator premises in Tampa, Florida.

While the scientific arrangement guarantees precision of the bending activity, it doesn't offer any understanding into the support's conduct in the wake of twisting, predominantly the impact of the upward web component on the distorted state of the top and base ribs that are independently bowed and the lingering stresses that form in the steel spine and web plates subsequent to bowing. Such impacts (fundamentally lingering stresses) are significant for weakness thought, particularly for steel spans in assistance as they are regularly consistent and exposed to pressure inversions. This paper leads a three-dimensional nonlinear limited component model for cold twisting a symmetric I-support (IPE600) thinking about both mathematical and material non-linearities. The limited component model offers profound understanding of the virus twisting interaction, predominantly on the greatness and dissemination of plastic (during stacking) and leftover (in the wake of dumping) stresses and strains that create in the web and spines of the steel area after each heap application. Utilizing FEA results, suggestions could be drawn for joining leftover impacts because of cold twisting in the plan of the steel bended brace in help.

The outcomes shown in the future relate to an ideal sweep of curve of $R=300 \mathrm{~m}$. The separating between supporting edges of the stacking outline is $S=1350 \mathrm{~mm}$ with a heap of $248 \mathrm{KN}$ applied from left to exactly at 4 unique continuous areas named as S2 (at 1200mm from left finish of brace), S3 (at 2400mm from left finish of brace), S4 (at 3600mm from left finish of support) and S5 (at $4800 \mathrm{~mm}$ from left finish of brace). Since the model is even, actuated parallel distortions ought to be equivalent in the top and base spines (this is affirmed later by 


\section{PEDAGOGY AND MODERN EDUCATION: TRADITION, EXPERIENCE AND INNOVATION}

Published: November 30, 2021 | Pages: 87-90

the limited component investigation). Just the counterbalances of the top spines are displayed from the limited component model.

All in all, the limited component model is utilized to explore three dimensional impacts that can't be given by the logical model. It ought to be noticed that most supports have beginning leftover anxieties worked in from manufacture of the straight brace which would influence its primary conduct during twisting. Without any information, these were not considered in the investigation.

As referenced before, the review introduced in this paper researched different stacking outline setups and radii of curve. Comes about because of differing the stacking succession and the dividing between the supporting arms on the distorted shape and instigated remaining burdens are introduced in the accompanying areas. Results are additionally displayed for the situations where the ideal span of shape is diminished.

CONCLUSION. This paper introduced results from three-dimensional limited component demonstrating of an IPE600 steel plate support bended utilizing a restrictive virus twisting framework. The economically accessible limited component program MSC SimXpert was utilized for this reason as it can represent both material and mathematical non-linearity. The steel support ribs and web were displayed utilizing four-noded isoparametric shell components with in-plane bowing firmness. The limited component model was looked at against results from a formerly evolved insightful model.

\section{REFERENCES}

1. Hassan, J. M., Tarrad A. H. and Abdullah, M. N. (2009) A dynamic modeling capability for subcritical vapor compression refrigeration system. Engineering and Technology Journal, 27 (13), p.2319-2338.

2. Hadjoannou M., Douthe C. and Gantes C. Influence of residual stresses induced by cold curving on the resistance of I-Section steel members. Eurosteel 2011, Aug 2011, Hungary. pp. 729-734. 
Published: November 30, 2021 | Pages: 87-90

3. Domanski, P. A. (1989) EVSIM An Evaporator Simulation Model Accounting for Refrigerant and One Dimensional Air Distribution. National Institute of Standards and Technology (NIST), Gaithersburg, USA.

4. Van Eijsenbergen, J. F. H. Duplex Systems: Hot-dip Glavanizing plus Painting, Amsterdam - London - New York - Tokyo: Elsevier, 1994, p. 61.

5. Lakes R. S. High damping composite materials: effect of structural hierarchy. J Compos Mater 2002;36(3):287-97. 
PEDAGOGY AND MODERN EDUCATION: TRADITION, EXPERIENCE AND INNOVATION

Published: November 30, 2021 | Pages: 91-93

\section{SOFTWARE PRODUCT FOR CLINICAL AND IMMUNOLOGICAL PROGNOSIS OF THE SEVERITY OF COVID-19}

Nodir Ruzimurodov

junior researcher, Institute of Immunology and human genomics of the Academy of Science of the Republic of Uzbekistan

Tamara Aripova

Academician, director of the Institute of Immunology and human genomics of the Academy of Science of the Republic of Uzbekistan

ABSTRACT: One of the global problems at the moment is the Coronavirus (COVID-19). Everyone already knows all the consequences of COVID-19. In addition, determining the course of the severity of the disease is also an important factor for both the patient and the medical staff. Until now, there are various methods and standards for the treatment of COVID-19. But for determining the severity of the disease, no standard or protocol has yet been defined. To solve this problem, we studied clinical and immunological tests in 109 patients and tried to create a program to predict the severity of COVID-19 in the early stages of the disease, so that, during the treatment for the severity of the disease, we started.

KEYWORDS: COVID-19, software, “CIP-COV.exe”, cytokines, immunity.

INTRODUCTION: The progress of clinical medicine to a certain extent depends on the level of diagnosis, prognosis and treatment of patients. The last decades have been characterized by a rapid growth in the number of diagnostic methods, the introduction of the latest electronic equipment, which makes it possible to identify the subtle mechanisms of the pathological process.

As everyone knows, to this day, the weight of the world suffers from coronavirus infection. The exact molecular mechanisms of COVID-19 mediated pathogenesis are still being investigated. However, lessons learned from SARS-CoV and MERS-CoV infections may reveal some of the key features of the pathologies associated with COVID-19 (1), as well as the molecular mediators and signaling pathways involved. Inoculation of SARS-CoV-2 of epithelial cells of the human respiratory tract in vitro causes cytopathic effects and cessation of beating 


\section{PEDAGOGY AND MODERN EDUCATION: TRADITION, EXPERIENCE AND INNOVATION}

Published: November 30, 2021 | Pages: 91-93

of cilia of epithelial cells, similar to the cytopathic effect observed during infection with SARSCoV. At the same time, to date, there is not a single treatment for coronavirus infection, as well as a prognosis for the course of COVID-19. But many authors offer treatment regimens depending on the severity of the disease (3).

The aim of the work was to develop integral characteristics of the clinical and immunological prognosis of the severity of the course of COVID-19 using a software product.

RESULTS: To solve this problem, a data array of 109 patients with various courses of COVID-19 was used. To enter the initial information into a computer for the purpose of its subsequent statistical processing, a special coding card was developed for the examination of patients, which included 20 clinical indicators related to the outcome and course of the disease.

The patients were divided into several groups: 1) control group (32 patients); 2) a group of patients with moderate severity (80 people); 3) a group of patients with severe course (29 patients).

The choice of the least squares method was due to the fact that in the study of medical processes, we are dealing with statistical data. That is why statistical data processing is carried out in almost every medical problem and serves as one of the stages of information processing.

Regression analysis is used to identify patterns, that is, to build mathematical models. And here the method of least squares is widely used, which is the basic method of regression analysis.

The calculations were performed on an IBM Pentium-type personal computer using the "STATISTICA-10" statistical software package (3).

The high value of the coefficient of determination of equations (3-7) testifies to the high efficiency of the obtained models. This served as the basis for the development on their basis of the software tool "Clinical and immunological prognosis of the severity of COVID-19 course" (CIP-COV.exe), for which the copyright certificate of the Patent Office of the Republic of Uzbekistan No. DGU 12771 dated 09.29.2021 was received.

DISCUSSION: With the help of this program, we have a chance to predict the severity of COVID19 with laboratory and immunological data. During hospitalization, in patients, as in the standard, a laboratory study is determined, such as a general blood test, a general urinalysis, a biochemical analysis, and also for an accurate diagnosis, we need to study the level of D-demir, procalcitonin and coagulogram. In addition to laboratory tests, we need to study the 


\section{PEDAGOGY AND MODERN EDUCATION: TRADITION, EXPERIENCE AND INNOVATION}

Published: November 30, 2021 | Pages: 91-93

immunological status. To determine the body's immune response, we proposed to study IL-1 $\beta$, IL-2, IL-6, TNF- $a$. These cytokines, as studied by foreign scientists, play a key role in the "cytokine storm". Based on the data of the above analyzes, if we write the answers to the program, then the program will give us a prognostic level of the severity of the disease, since this will be a key moment for us in determining the pathogenetic treatment. After establishing an accurate diagnosis, it will be easier for doctors to determine the severity of the disease, and will focus on the treatment and rehabilitation of patients with COVID-19.

\section{REFERENCES}

1. Halpin SJ, Mclvor C, Whyatt G, et al. Postdischarge symptoms and rehabilitation needs in survivors of COVID-19 infection: a crosssectional evaluation [published online ahead of print July 30, 2020]. J Med Virol. 2020:1-10. https://doi.org/10.1002/jmv.26368

2. Kremer N.Sh. Probability theory and mathematical statistics: Textbook for universities. M., UNITY-DANA, 2001

3. Wu Z, McGoogan JM. Characteristics of and important lessons from the coronavirus disease 2019 (COVID-19) outbreak in China: summary of a report of 72,314 cases from the Chinese Center for Disease Control and Prevention. JAMA. 2020;323(13):1239-1242. 


\title{
TRAFFICKING IN HUMAN BEINGS IS A TRANSNATIONAL CRIME Nodir Ortiqov \\ Trainee, Academy Of The Armed Forces Of The Republic Of Uzbekistan
}

\author{
Obidjon Sayfiddinov \\ Mayor, University Of Public Safety, Tashkent, Uzbekistan
}

ABSTRACT: This article discusses the transnational crime of human trafficking. It is known that today there are more than 9,000 non-governmental, non-profit organizations in the country, about 100 of which are working to combat human trafficking. The law defines nongovernmental non-profit organizations as one of the organizations assisting government agencies in this area, and clearly defines their powers and responsibilities.

KEYWORDS: transnational crime, human trafficking, non-profit organizations, country, government agencies, powers, responsibilities.

INTRODUCTION: There are a number of global problems on our planet, including transnational crimes such as direct human trafficking. From year to year, the number of victims of this disease is growing. Each of these crimes, which knows no territory or borders, poses a serious threat to the development of society and the development of states. How disgusting it looks when a heinous crime such as human trafficking violates human life, freedom and rights and tramples on its will, destiny and future. It should be noted that today the increase in human trafficking, ie the use of human beings as a commodity, in other words, as an object of human trafficking, is a violation of their rights and freedoms:

- Illegal activities such as human trafficking are becoming a source of income for groups of one or more members, meaning that they are trying to make a living without any hard work;

- In the simplicity of the victims of human trafficking, in their indifference to the fate and future of themselves and their loved ones. In other words, as a result of their light and careless attitude towards the concept of free life, which is the highest blessing, they become the prey of the traffickers, or rather their easy source of income; 


\section{PEDAGOGY AND MODERN EDUCATION: TRADITION, EXPERIENCE AND INNOVATION}

Published: November 30, 2021 | Pages: 94-97

- When traffickers enter into the trust of their acquaintances, close relatives, that is, cause them to become victims of human trafficking;

- The humiliation of victims of human trafficking, the various physical or mental pressures used against them, or the violation of their own borders; not to apply to law enforcement agencies for fear of engaging in illegal labor activities without any state registration in a foreign country;

THE MAIN FINDINGS AND RESULTS. Combating Trafficking in Human Beings In the late 19th and early 20th centuries, there was widespread migration of women from Europe to the Americas and North Africa, as well as trafficking in women to Europe. In order to put an end to this phenomenon, two conferences were held in Paris in 1902 and 1910, and the World Convention Against the Trafficking in White Slaves was adopted. The Convention was later supplemented by the Global Conventions on the "Elimination of Trafficking in Women and Children" and the "Elimination of Trafficking in Adult Women". Subsequent historical processes in the fight against human trafficking have gradually developed, and in 1948 the Universal Declaration of Human Rights was adopted. This is followed by the "European Convention on Human Rights", the "Convention on Slavery", the Additional Convention on the "Elimination of Slavery", The Convention on the "Rights of the Child" and the Convention on the "Elimination of All Forms of Discrimination against Women" have been adopted and are now in force in many countries around the world.

In 2013, the United Nations declared July 30 as World Anti-Trafficking Day. Currently, this type of crime, which is an integral part of transnational organized crime, is widespread around the world. Experts from the United Nations and the International Organization for Migration estimate that the number of victims is in the millions. It is worrying that the majority of victims of human trafficking are women and children.

It would be wrong to consider human trafficking only as a problem of the Republic of Uzbekistan, because today the crimes related to human trafficking are widespread in many countries and are of concern to the world community. Sadly, human trafficking-related crime is on the rise: vulnerable segments of the population - unemployed citizens, women in difficult life situations and minors who have been left out of the care and attention of their parents. that they seem to have solved their problems and are using them for their own selfish ends. 


\section{PEDAGOGY AND MODERN EDUCATION: TRADITION, EXPERIENCE AND INNOVATION}

Published: November 30, 2021 | Pages: 94-97

The Convention for the "Suppression of Transnational Organized Crime", adopted by the United Nations General Assembly on 15 November 2000, also provides for the prevention, suppression and enforcement of trafficking in human beings, especially women and children. an additional penalty protocol was also ratified. During the years of independence, a number of agreements and treaties were signed with foreign countries on combating organized crime, including dangerous forms of human trafficking.

The Law of the Republic of Uzbekistan “On Combating Trafficking in Human Beings" was adopted on April 17, 2008. In order to further improve and bring it into line with modern requirements, it was amended and supplemented. The new edition was adopted on August 17, 2020. The need to revise the law is due to the fact that today there are no clear rules for the protection and assistance to victims of trafficking in human beings, and the specifics of combating trafficking in minors, including the legal status of identification, assistance and protection explained by.

The new version of the law takes into account these aspects. In particular, the basic concepts and principles of the field, the norms of its state regulation, the competent state bodies, the national commission, the territorial commissions and the norms of the national speaker are clearly defined. It is known that today there are more than 9,000 nongovernmental non-profit organizations in the country, about 100 of which are working to combat human trafficking. The law defines non-governmental non-profit organizations as one of the organizations assisting government agencies in this area, and clearly defines their powers and responsibilities. At the same time, in contrast to the current law, the new version of the law defines the procedure for ensuring the social rehabilitation and adaptation of victims of trafficking and the confidentiality of information about victims and the security measures and other guarantees provided to them. In addition, the concepts of identification and redirection of victims of human trafficking, which did not exist before in our national legislation, are defined in a separate chapter. It was noted that the National Commission for Combating Trafficking in Human Beings and Forced Labor is a collegial body that coordinates the activities of public authorities and other organizations in the fight against human trafficking. It was noted that the decisions of the National Commission must be implemented by public authorities and citizens' self-government bodies, and are of a recommendatory nature for non-governmental non-profit organizations. 
CONCLUSION. In short, the adoption of the law will serve to guarantee the protection of the rights and legitimate interests of victims of human trafficking.

\section{REFERENCES}

1. Turdiyev, B. (2021). Spiritual Renewal: THE new decree and the strategy of life-inspiring reforms. Центр Научных Публикаций (buxdu. uz), 6(6).

2. Mamatmuratovna, K. D., \& Gapparovich, T. S. (2021, April). SYSTEM OF PREPARATION OF YOUNG PEOPLE FOR SPIRITUAL, LEGAL AND LEGAL EDUCATION. In Archive of Conferences (Vol. 23, No. 1, pp. 168-171).

3. Norqulova, D. Z., \& Sh, U. B. THE CONCEPT OF FORCED LABOR.

4. Savona, E. U., \& Stefanizzi, S. (Eds.). (2007). Measuring human trafficking: Complexities and pitfalls. Springer Science \& Business Media.

5. Turdiyev, B. (2021). GENDER EQUALITY IN UZBEKISTAN: REFORM AND STRATEGY STRATEGY. ЦЕНТР НАУЧНЫХ ПУБЛИКАЦИЙ (buxdu. uz), 6(6).

6. Wilson, D. G., Walsh, W. F., \& Kleuber, S. (2006). Trafficking in human beings: Training and services among US law enforcement agencies. Police Practice and Research, 7(02), 149-160.

7. Jordan, A. D. (2002). Human rights or wrongs? The struggle for a rights-based response to trafficking in human beings. Gender \& Development, 10(1), 28-37.

8. Albanese, J. (2007). A criminal network approach to understanding \& measuring trafficking in human beings. In Measuring human trafficking (pp. 55-71). Springer, New York, NY.

9. Skrivankova, K. (2006). Combating trafficking in human beings. International Review of Law Computers \& Technology, 20(1-2), 229-232. 